\title{
Analyzing Atmospheric Circulation Patterns Using Mass Fluxes Calculated from Weather Balloon Measurements: North Atlantic Region as a Case Study
}

\author{
Michael Connolly ${ }^{1}$, Ronan Connolly ${ }^{1,2, * \mathbb{D}}$, Willie Soon ${ }^{2,3}$, Víctor M. Velasco Herrera ${ }^{4}(\mathbb{D}$, \\ Rodolfo Gustavo Cionco ${ }^{5}$ (i) and Nancy E. Quaranta ${ }^{5}$ \\ $1 \quad$ Independent Researcher, D01 Dublin, Ireland; michael@ceres-science.com \\ 2 Center for Environmental Research and Earth Sciences (CERES), Salem, MA 01970, USA; \\ willie@ceres-science.com \\ 3 Institute of Earth Physics and Space Science (ELKH EPSS), H-9400 Sopron, Hungary \\ 4 Laboratorio de Inteligencia Artificial, Instituto de Geofisica, Radiacion Solar, Universidad Nacional \\ Autonoma de Mexico, Mexico City 04510, Mexico; vmv@igeofisica.unam.mx \\ 5 Scientific Research Commission of Buenos Aires (CICPBA), Environmental Research Group (GEA-UTN), \\ National Technological University (UTN), San Nicolás 2900, Buenos Aires, Argentina; \\ gcionco@frsn.utn.edu.ar (R.G.C.); nquaranta@frsn.utn.edu.ar (N.E.Q.) \\ * Correspondence: ronan@ceres-science.com
}

\section{check for} updates

Citation: Connolly, M.; Connolly, R.; Soon, W.; Velasco Herrera, V.M.; Cionco, R.G.; Quaranta, N.E. Analyzing Atmospheric Circulation Patterns Using Mass Fluxes Calculated from Weather Balloon Measurements: North Atlantic Region as a Case Study. Atmosphere 2021, 12, 1439. https://doi.org/ $10.3390 /$ atmos 12111439

Academic Editor: Maxim G. Ogurtsov

Received: 6 October 2021

Accepted: 26 October 2021

Published: 30 October 202

Publisher's Note: MDPI stays neutral with regard to jurisdictional claims in published maps and institutional affiliations.

Copyright: (c) 2021 by the authors. Licensee MDPI, Basel, Switzerland. This article is an open access article distributed under the terms and conditions of the Creative Commons Attribution (CC BY) license (https:// creativecommons.org/licenses/by/ $4.0 /)$.
Abstract: In recent decades, efforts to investigate atmospheric circulation patterns have predominantly relied on either semi-empirical datasets (i.e., reanalyses) or modeled output (i.e., global climate models, GCMs). While both approaches can provide important insights, there is a need for more empirical data to supplement these approaches. In this paper, we demonstrate how the application of relatively simple calculations to the basic measurements from a standard weather balloon radiosonde can provide a vertical profile of the horizontal atmospheric mass fluxes. These mass fluxes can be resolved into their meridional (north/south) and zonal (east/west) components. This provides a new useful empirical tool for analyzing atmospheric circulations. As a case study, we analyze the results for a selected five stations along a fairly constant meridian in the North Atlantic sector from 2015-2019. For each station, we find the atmospheric mass flux profiles from the lower troposphere to mid-stratosphere are surprisingly coherent, suggesting stronger interconnection between the troposphere and stratosphere than previously thought. Although our five stations span a region nominally covered by the classical polar, Ferrel and Hadley meridional circulation cells, the results are inconsistent with those expected for polar and Ferrel cells and only partially consistent with that of a Hadley cell. However, the region is marked by very strong prevailing westerly (west to east) mass fluxes for most of the atmosphere except for the equatorial surface easterlies ("trade winds"). We suggest that the extension of the techniques of this case study to other stations and time periods could improve our understanding of atmospheric circulation patterns and their time variations.

Keywords: weather balloon data; molar densities; troposphere-stratosphere correlations; atmospheric mass motion/circulation

\section{Introduction}

"Of all the phrases in everyday use in meteorology the term 'the general circulation of the atmosphere' is high on the list for meaning 'most things to most people'. This is not surprising for in the literature under the General Circulation heading we find everything from vague qualitative ideas and imaginative cellular circulations to intricate mathematical analyses, and from surface-bound observational studies to complex investigations of three-dimensional motion extending well above the tropopause."-Dr. Gilbert B. Tucker, "The general circulation of the atmosphere" (1962) [1] 
It is nearly 60 years since Tucker made the observation quoted above, yet it is still remarkably relevant. Terms such as "the general circulation of the atmosphere", "atmospheric general circulation" or simply "atmospheric circulation" are clearly very important for describing both short-term weather patterns (e.g., meteorology) and longer-term climatic changes (e.g., climatology). However, as Tucker observed, the exact meanings of these terms are sufficiently loose that they can mean different things to different people at different times.

When we adhere to what Tucker described as "vague qualitative ideas", the definitions are generic enough to describe the overall subject matter, but little more. These definitions typically are fairly uncontroversial, yet do not reveal much. Knox and Knox (2017) give a representative example: "The general circulation of the atmosphere (also known as the planetary circulation) is, in its most basic sense, the large-scale flow of the atmosphere across the entire planet. It is described by averages of horizontal and vertical motion of air over time and space as well as temporal and spatial deviations from the average conditions" [2]. However, as researchers try to pin down the definition into more specific and practical meanings the details become more amoeba-like.

In this paper, we present a new set of techniques that can be applied to the data from weather balloon soundings (sometimes called "radiosondes") such as NOAA NCEI's Integrated Global Radiosonde Archive (IGRA) [3-5], as well as to other equivalent atmospheric profile samplings. These techniques allow us to directly calculate the horizontal mass fluxes at all points sampled by the weather balloons. In this manuscript, we will apply these techniques to five years of data (2015-2019) for five stations sampled from a fairly constant meridian in the North Atlantic sector as a case study to demonstrate the utility of these calculations.

Even though this case study represents a relatively small geographical region and a relatively short period, we already find that our analysis provides several new insights which have implications for the current understanding of atmospheric circulations. However, ultimately, we hope that our case study will encourage the extension of these new techniques to analyze more stations, more regions, and more time periods.

We believe that this will provide much deeper insights into atmospheric circulation patterns, and hopefully finally allow us to gain a deeper understanding of the general atmospheric circulation. Therefore, before we turn to these new techniques and our case study, we will first provide an introductory review of the current views on atmospheric circulations and how they arose.

\subsection{Historical Development of the Current "Three-Cell General Circulation Model"}

Tucker's "imaginative cellular circulations" referred to a theoretical three-dimensional cartoon schematic of the general atmospheric circulation consisting of three large cellular atmospheric circulations in each hemisphere which was developed between the 17th and 19th centuries. As has been well-documented elsewhere [2,6-9], this schematic was developed to try and explain the existence of the "trade winds" used by sailors, i.e., prevailing "easterlies" (surface winds moving from the east to west) in the tropics. Halley and later Hadley argued on theoretical grounds that the trade winds are a consequence of the equator-to-pole surface temperature gradient (due to the greater incoming sunlight at the tropics). Both Halley and Hadley proposed that the warm air at the tropics ascends at the equator, then once aloft heads towards the poles where it cools, descends, and then returns towards the equator. That is, they both argued that a three-dimensional convective circulation cell should exist between the equator and each pole. Halley argued that the surface return winds were easterly in nature because of the diurnal orbit of the Sun around the equator. However, Hadley argued that the easterly component arose because the Earth spins daily on its own axis (essentially what later became known as Coriolis rotation) [8]. In the 19th century, Ferrel developed this theoretical model further and suggested that there were three separate cells from the equator to the pole. This also offered an explanation for the prevailing "westerlies" (surface winds moving from west to east) at the mid-latitudes. 
The first two of these cells are now known as the "Hadley" and "Ferrel" cells in recognition of their work:

1. A "direct" Hadley cell from equator to about $30^{\circ}$ latitude that is thermally driven by the heating from the large amount of incoming tropical sunlight.

2. An "indirect" Ferrel cell between about $30^{\circ}$ and $60^{\circ}$ latitude that is driven by the circulations of the cells on either side of it.

3. A "direct" Polar cell from about $60^{\circ}$ latitude to the pole that is thermally driven by the cooling of the atmosphere at the poles.

By the early 20th century, this theoretical "three cell" model of the general atmospheric circulation was widely accepted by the meteorological community. However, although the model makes theoretical predictions about the upper atmosphere, it was entirely based on what Tucker referred to as "surface-bound observations", i.e., observations of the prevailing surface wind patterns over the oceans. It was only in the late-19th century and early 20th century that it became possible to make direct measurements of the upper atmosphere using weather balloons.

After World War 2, there was a renewed interest in weather prediction, and also an increasing amount of measurements from weather balloons. Therefore, from the 1940s to 1970s, several groups (including Tucker's) finally began carrying out the "complex investigations of three-dimensional motion extending well above the tropopause" referred to by Tucker.

Much of the initial attention from these investigations was focused on the discovery that the clearest and most consistent features of the upper atmospheric circulation were the unanticipated and newly-discovered "jet streams" - relatively narrow bands of high velocity horizontal zonal winds at fairly discrete latitudes near the top of the troposphere (below the tropopause/stratosphere) [10,11]. However, since the prevailing views at the time assumed that the main circulations should be those predicted by the three-cell model, a second research focus attempted to explain why the evidence for these three cells from the available weather balloon data was at best ambivalent. Rossby and Willett (1948) summarized the problem with the following [11]:

"(1) In the tropics there exists no horizontal latitudinal temperatures gradient such as is required by a thermally direct cell of the Hadley type. Consequently, the east winds do not decrease with height, but extend to the top of the troposphere, even with some increase near the tropopause.

(2) Furthermore, the wind structure in the tropics is much too complex, indicating, instead of a single thermally direct cell, probably two or more cells which are partly forced in character.

(3) In middle latitudes, far from decreasing with height, the west winds increase to the jet characteristics of the circumpolar vortex at the top of the troposphere."

This led to considerable debate over how relevant the "mean meridional overturning circulation" (MMOC or MOC) of each of the cells in the three-cell model is for describing the observed winds throughout the atmosphere [12-16].

Rossby and others [11,14,16-24] argued that apart from the surface winds (which the cellular model was developed to explain), the measured winds in the atmosphere appeared to be dominated by factors other than the expected MOC. The term "eddies" was used to collectively refer to these factors. They did not dispute the theoretical thermodynamic rationale for the existence of the three cells [25]. However, they suggested that on a day-today basis, these "eddies" dominated, and therefore any systematic component from the MOC could be completely obscured. Two classes of "eddies" were generally considered: "transient eddies" (i.e., fluctuations due to the passage of short-term weather systems), "standing eddies" (larger-scale zonal waves from semi-permanent systems) [26]. It was argued that these eddies dominated over the expected MOC in terms of: the observed winds [11]; transport of angular momentum [14,16-18]; transport of kinetic energy [21,22]; transport of atmospheric particles [24]; and more broadly, the general circulation of the 
atmosphere [11,21-24]. Eddies could even potentially explain the existence of prevailing easterlies and westerlies [20].

These views were disputed by multiple researchers (including Tucker) who argued that the three cells—in particular, the Hadley cell—were dominant features of the general circulation of the atmosphere $[15,27-36]$. Some argued that the three-cell model offered the best theoretical explanation for the observed surface winds [27,28,31]. Several groups suggested that circulation patterns consistent with the three-cell model could be found in the balloon measurements provided that the data was suitably processed and averaged [32-36], or by using "geostrophic wind" calculations derived from height and pressure measurements [29]. These groups gained some support from the fact that the seminal [13] early computer simulation of the general circulation by Phillips (1956) appeared to spontaneously simulate three cells similar to the Hadley, Ferrel and polar cells [30].

Over the years, various studies attempted to resolve the disputes between the rival schools of thought by showing both views had validity. Holopainen argued that in the extratropics, the eddies were indeed the dominant circulation mechanism ("Rossby regime"), while nearer the equator the cellular model dominated ("Hadley regime") [37,38]. He also argued that the Hadley regime was relatively small in the summer hemisphere $[37,38]$. Indeed, an inspection of Figure 3 of Vuorela and Tuominen (1964)'s study of the Northern Hemisphere summer reveals that the Hadley cell they found at the equator did not extend as far as $10^{\circ} \mathrm{N}$ [39]. Hastenrath (1969) confirmed that "There is evidence for a strong tropical Hadley cell with a temperate latitude indirect circulation during the winter season. During summer, the northern Hadley cell is weaker and displaced poleward" [40]. Murray et al. (1969)'s analysis of the mean meridional velocities at $30^{\circ} \mathrm{N}$ revealed two factors that may have contributed to the controversy [41]. (i) Although they found a net northerly flow in the lower troposphere and a net southerly flow in the upper troposphere consistent with a Hadley cell, the speeds involved were quite modest: a maximum of $0.38-0.70 \mathrm{~m} / \mathrm{s}$ for the winter and $0.07-0.15 \mathrm{~m} / \mathrm{s}$ for the summer [41]. (ii) They suggested that the monsoon seasons probably interfered with these "Hadley patterns" [41].

One of the main predictions of the three-cell model relates to vertical velocities, e.g., the Hadley cell predicts a vertical rise of warm air at the equator-side of the cell and a vertical descent of cooler air at the poleward-side. However, because there are no direct measurements of vertical wind speeds, the current estimates are all calculated not measured. Yet, while the studies identifying a strong Hadley cell calculated these vertical velocities should be present, Newell (1963) noted that the calculated vertical speeds of less than $1 \mathrm{~cm} / \mathrm{s}$ (i.e., less than $0.864 \mathrm{~km} /$ day) were " ... rather low-it would take a small particle more than 20 days to pass from the tropopause to the surface" [24]. Hence, he suggested that vertical transport in the atmosphere is probably dominated by the eddies rather than the MOC [24].

By the early 1970s, this appears to have led to a nuanced compromise between the rival groups where it was conceded that the cells might be there but not necessarily the dominant features of the "general circulation" as initially assumed until the 1940s. Several studies using weather balloons agreed that the Hadley cell was quite prominent in each hemisphere during its winter, but less prominent in the summer season [42-45]. Oort and Rasmusson (1970) also found evidence for the other two cells, but noted that these were much weaker, i.e., they only found a "rather weak Ferrel circulation ( . . . ) and a very weak polar circulation" [43]. Starr et al. (1970) agreed and emphasized that compared to the zonal wind circulations (i.e., westerlies and easterlies), the meridional circulations (i.e., northerlies and southerlies) were "not so well defined" [44]. Further, they noted that they got different estimates for each of the cells depending on which of six versions of analysis they applied. They warned that " $(\mathrm{t})$ he results illustrate the difficulty in determining the mean meridional motion by direct observations. The sensitivity of this quantity both to the observational sampling and to small changes in analysis schemes is evident" [44].

Nonetheless, despite the nuance of the above compromise, this concession appears to have led many to believe that the battle had been won by the defenders of the three-cell 
model, e.g., Schulman (1973) claimed that "the three cell meridional circulation has now been well established" [45]. Several theoretical modeling studies in the 1970s and 1980s [46-48] pointed out that the observed Hadley cell could not be explained in terms of "eddies" alone and proposed theoretical "eddy-free" models which provided an explanation not only for the Hadley cell but surface westerlies and easterlies and the jet streams. These models predicted that the Ferrel and polar cells should also be prominent. Refinements of these models also offered an explanation as to why the winter hemisphere Hadley cell appeared to dominate over the summer hemisphere [48].

This appears to have led to the situation where the modern student of meteorology or climatology is again encouraged to study "the three-cell model" as one of the most important aspects of the "general circulation"-albeit a more nuanced one $[2,7-9,49]$ than that which would have been learned by early 20th century students. However, we caution that the concerns raised by the "pro-eddy" camp remain valid. Indeed, more recent studies have shown that re-introducing "eddies" leads to a more realistic modeling of the Hadley cell $[50,51]$. Meanwhile, the relevance of each of the three cells for describing the general circulation has been questioned: Wang et al. (2005) argue that the classical "Ferrel cell" is contradicted by modern observations [52]; Qian et al. argue that the classical "polar cell" is better split up into two separate mini-cells [53-55]; Even for the tropical regions where the clearest "cell" (i.e., the winter Hadley cell) is found, the zonal circulation patterns-including the tropical "Walker cells" and the related El Niño-Southern Oscillation (ENSO) phenomenon-and monsoons are considered to be at least as important for understanding the tropical circulations as the meridional circulation [56-62]. On this latter point, Schwendike et al. argue that the interconnections in the tropics between the Hadley and Walker circulations lead to so much spatial and temporal variability that it is better to partition the tropical circulations into "local Hadley" (i.e., meridional) circulation and "local Walker" (i.e., zonal) circulation components rather than assuming a single "Hadley cell" and "Walker cell" [63-65]. Others emphasize that land/ocean differences effectively split up the idealized "global Hadley cell" into several small regionally distinct "cells" separated by regions with non-Hadley circulations [66].

\subsection{Regional Atmospheric Circulation Patterns and the Relationships between Them}

At any rate, following the apparent resolution by the late-1960s/early-1970s of the debate over the importance of the three cells, much of the focus on "the general circulation of the atmosphere" has shifted towards how these three "meridional overturning circulation cells" interlock with other "circulation patterns". The relationship between the Hadley cell and ENSO, Walker cells, and the monsoons has already been mentioned [56-65]. It has long been argued that the "summer Hadley cell" is less pronounced due to the influence of the monsoons [41,45] and ENSO [56]. Variability in the Hadley cell has also been linked to the quasi-biennial ( 28-29 months) oscillation (QBO) in the prevailing tropical stratospheric winds between easterlies and westerlies [42]. Meanwhile, it is believed that variability in the Southern and Northern Annular Modes (SAM and NAM respectively) is correlated with the corresponding Ferrel cell and the poleward branch of the corresponding Hadley cell [67-69]. The NAM, also called the Arctic Oscillation (AO), appears to be well correlated to temperature and precipitation trends in Northern Eurasia [67,70,71]. The $\mathrm{AO}$ is itself highly correlated to another atmospheric index, the North Atlantic Oscillation (NAO) [71,72]. However, Qian et al. (2017) argue that after their proposed splitting of the "polar cell" into two cells (mentioned above), the changes in the strength of these two components of the "polar cell" explain more of the northern hemisphere climate changes than the $\mathrm{AO} / \mathrm{NAO}[55]$.

\subsection{Proposed Links between Solar Activity and Atmospheric Circulations}

The theme of this special issue is, "Links between solar activity and atmospheric circulation" (https://www.mdpi.com/journal/atmosphere/special_issues/solar_atmosphere, accessed on 25 October 2021). Although we personally are actively interested in the in- 
fluence of solar activity on the Earth's climate, e.g., [73-76], we will be predominantly focusing in this paper on new analytical tools for studying atmospheric circulation. The calculations described here can be applied to most weather balloon soundings, including the global historic archive of NOAA NCEI's Integrated Global Radiosonde Archive (IGRA) $[3,5,77]$. Therefore, our hope is that the empirical techniques we present through this case study of a specific region (European sector of the North Atlantic) will offer new useful methods for analyzing atmospheric circulation patterns that can be retrospectively applied by researchers to the IGRA dataset or other similar archives as well as to new soundings.

We hope that the extra insights from these techniques will help identify more nuanced, yet robust, descriptions of the various atmospheric circulation patterns. We expect that this will make it easier to accurately identify those aspects which are influenced by solar activity and other factors.

Nonetheless, there is already a sizeable literature indicating that solar activity appears to have a significant influence on many aspects of the atmospheric circulation patterns we described above. Therefore, it may be of interest to the reader to briefly review some representative studies which have already identified potential links between solar activity and the various atmospheric circulation patterns. Here, for brevity, we highlight just a few representative studies, with an emphasis on recent studies.

Several studies have argued for solar signals in Hadley and Walker cell circulations [78]; ENSO [79]; the occurrence of "El Niño Modoki" events [80]; NAO [72,81-87]; NAM [88]; Madden-Julian Oscillation (MJO) events [89,90]; and the Quasi-Biennial Oscillation (QBO) [91,92]. Recently, some researchers have noted that there seem to be relationships between the strength of MJO events and the phase of the QBO [93], although the latest Coupled Model Intercomparison Project Phase 6 (CMIP6) global climate models do not appear to be able to replicate these QBO-MJO connections [94]. At any rate, interactions between these and other "centers of action" [95] could potentially lead to complex Sun-climate relationships that may manifest differently on a regional scale as well as temporally [90,96-106]. For a more detailed review of potential links between solar activity and atmospheric circulation and/or regional climatic variability we recommend Sections 2.6.1 and 2.6.3 of Connolly et al. (2021) [76].

\subsection{Empirical, Semi-Empirical and Theoretical/Model-Based Approaches to Analyzing Atmospheric Circulations}

Since the 1990s, there has been a striking shift in the main tools used for analyzing atmospheric circulations. In the earlier debates of the 1940s-1970s, most research was based on: (i) theoretical calculations; (ii) direct weather balloon measurements; (iii) climatological maps interpolated from weather balloon measurements; and (iv) values derived from the application of theoretical calculations to balloon measurements. However, since the 1990s, there has been an increasing shift away from direct empirical measurements to the use of semi-empirical "reanalysis" datasets which assimilate various data sources (including some weather balloon measurements) using a numerical model to provide three-dimensional estimates of how the entire atmosphere has changed over time [66,107-113]. Reanalyses essentially use similar models to those used by climate models but adjust the model output to be more consistent with various subsets of empirical observations (including weather balloon measurements, satellite measurements, etc.) [66,107-113]. Reanalyses, therefore, offer a useful "semi-empirical" bridge between purely empirical observations such as weather balloon measurements and the theoretical output from climate models. Meanwhile, the CMIP3, CMIP5 and CMIP6 projects to provide Global Climate Model (GCM) results for the 4th, 5th, and 6th assessment reports (respectively) of the Intergovernmental Panel on Climate Change (IPCC) have inspired a lot of model-driven research into atmospheric circulation patterns using the output from these models, e.g., [109,114-119].

Estimates from reanalyses tend to show stronger and more distinct Hadley and Ferrel cells than those from direct weather balloon measurements [107]. Although, while they suggest a southern polar cell, they are less clear about the northern polar cell [53-55,107]. 
This has prompted several groups to use reanalyses to study whether there have been any long-term trends in the cells (particularly the Hadley cells) from climate change [108-112]. Many of these studies have suggested that the Hadley cell has been expanding in recent decades, e.g., [108-112]. Most reanalyses only begin in the 1950s or 1970s and can only evaluate recent decades. However, Liu et al. (2012) found by using the longest reanalysis ("20CR", beginning in 1871) that these recent changes were less than earlier changes in the late-19th/early-20th centuries [111].

On the other hand, while the GCMs predict that the Hadley cells should expand in the future as a result of the models' projected global warming [114], several studies have argued that the trends implied by the models are significantly smaller than those implied by the reanalyses $[108,109,116,120-124]$. Some studies even suggest that the models imply a slight weakening of the Hadley cells in recent decades rather than the strengthening implied by the reanalyses $[119,122,124]$.

The apparent disagreements between the models and reanalyses over recent trends in the Hadley cells have led to a considerable ongoing debate over (i) how significant the alleged discrepancies are and also over (ii) which of the estimates are "more reliable". Some studies have suggested that the fault may lie with the models $[109,116,120]$. Some suggest that the fault may lie with the reanalyses [119,123-127]. However, others stress that the fault could potentially lie with either or both $[108,122,128]$.

Meanwhile, other studies suggest that the apparent discrepancies might not be as significant as initially assumed $[115,117,118]$. One counter-argument notes that ensemble averages of multiple GCM hindcasts dramatically underestimate the so-called "internal variability" of individual GCM runs. Hence, it is suggested that if this extra variability is accounted for, the reanalysis trends are no longer "inconsistent with" the modeled trends $[115,117,121]$. This is a debate we have discussed elsewhere in detail in terms of a different climatic index (i.e., snow cover trends) [129]. However, it has also been suggested that the apparent differences in the trends disappear when different metrics are used for quantifying the Hadley cells—or more generally, "the tropical belt" [117,118].

Given these ongoing debates over the apparent differences between the trends of the semi-empirical reanalyses and modeled trends of the GCMs, many of the above studies have called for the development and analysis of more atmospheric circulation metrics that have been derived directly from empirical observations (chiefly weather balloons) [117,123-128]. In this paper, we will present a new metric that could provide insights into the above debates, and more generally, analyze atmospheric circulations.

We should stress the distinction between empirical, semi-empirical, theoretical, and modeling data. Scientific research aims to develop theories and models that can reliably and consistently explain and predict empirical observations. Ideally, whenever this has been achieved, these four classes of data should all be equivalent. However, while scientific research is still ongoing, the empirical and theoretical data will often disagree with each other $[94,108,109,116,120-124,129,130]$. Indeed, identifying where and why these disagreements arise often inspires future scientific research. Therefore, as a community, we should be inspired rather than disheartened whenever such conflicts arise.

Over the last century, many different empirical techniques have been developed for taking atmospheric measurements [131]. Each technique has its pros and cons. For instance, ground-based remote sensing techniques based on radar, lidar, or sonar can provide continuous high-resolution information for the lowest part of the troposphere, i.e., the "planetary boundary layer" or "atmospheric boundary layer" [132-135]. However, these measurements are mostly confined to the first $2 \mathrm{~km}$ of the atmosphere-although microwave radiometers can provide some measurements for the first $5 \mathrm{~km}$ [133]. Some groups have also proposed the use of atmospheric radioisotopes as combined proxies for several atmospheric circulation characteristics [136].

Above the atmosphere, remote sensing by satellites can provide regular atmospheric measurements for much of the upper atmosphere (mesosphere and higher). Indeed, Baron et al. (2018) suggest that future satellite sounders should be capable of providing useful 
wind measurements for the upper stratosphere region between 30 and $90 \mathrm{~km}$ [137]. This is the region above where the weather balloons discussed in this paper sample because most weather balloons burst below 30-35 km [3,5,77,138], although so-called "zero pressure balloons" (ZPBs) can reach $40 \mathrm{~km}$ [138].

Aircraft measurements can also provide valuable data for within the troposphere, e.g., we note Zhang et al. (2019)'s recent atmospheric profiles for the troposphere derived from U.S. airport traffic [139]. However, for directly studying the troposphere to stratosphere regions, weather balloons remain one of our most powerful tools. In particular, the IGRA dataset used in this study currently provides more than half a century of archived weather balloon soundings from more than 1000 stations as well as some more limited data for the early-20th century [5].

\subsection{Aims of This Case Study}

In a 2014 series of working papers, two of us (MC and RC) showed how a simple calculation that could be applied to the pressure and temperature measurements of a weather balloon sounding reveals the vertical profile of the atmosphere's "molar density", i.e., the number of moles of atmosphere per $\mathrm{m}^{3}$ [140-142]. [Note for non-chemists: a mole is a unit to precisely describe the amount of a substance, where 1 mole $=6 \times 10^{23}$ molecules]. In this paper, we show how these calculations can additionally be combined with the corresponding horizontal wind velocities and humidity measurements to derive a vertical profile of the horizontal atmospheric mass fluxes, i.e., the rates of atmospheric mass transport at each point in the atmosphere sampled by the balloon. In principle, these techniques could also be applied to other atmospheric datasets that provide simultaneous temperature, pressure, humidity, and wind velocities such as Zhang et al. (2019)'s aircraft traffic-derived atmospheric profiles mentioned above [139].

As a case study, we will present and discuss the results for five years of weather balloon soundings (2015-2019) from five stations. These five stations were selected from a fairly constant meridian in the North Atlantic sector and cover a latitudinal range that nominally should sample the northern hemisphere polar, Ferrel and Hadley cells discussed above. Therefore, we will briefly discuss the results from these five stations in terms of the various atmospheric circulation debates reviewed above. We will also present some preliminary frequency analyses of the time series.

Finally, we will offer some recommendations on how these new empirical techniques could be used for improving our understanding of atmospheric circulations. In particular, as mentioned above, weather balloon sounding archives such as the IGRA dataset (which we use here) provide more than half a century of historical data for more than 1000 weather balloon stations globally [5]. Therefore, we actively encourage more research into retrospectively analyzing weather balloon archives such as this using our new techniques.

\section{Data and Methods}

\subsection{How to Calculate the Atmospheric Mass Fluxes from a Weather Balloon Sounding}

Weather balloons, with data records maintained at NOAA NCEI's (https: / www.ncdc. noaa.gov / data-access/weather-balloon/integrated-global-radiosonde-archive, accessed on 10 November 2020) Integrated Global Radiosonde Archive (IGRA) [3,5,77], have been routinely launched from more than 1000 weather stations around the world, between 1 and 4 times a day, since the 1950s or so. These balloons provide pressure (P), temperature (T), horizontal wind velocities, and water content measurements throughout their vertical ascent through the troposphere, tropopause, and stratosphere until they burst (typically at $\sim 30-35 \mathrm{~km}$ altitude). In Figure 1, we illustrate how to use these measurements to derive the atmospheric mass flux profiles for a typical weather balloon sounding (Ireland, 17 March 2016, 12:00 LST). Figure 2 presents the same results as Figure 1 but uses height/altitude as the $y$-axis instead of atmospheric pressure.

A key part of the analysis in this paper is a recognition of the fact that if you know the temperature $(\mathrm{T}$, units of $\mathrm{K}$ ) and pressure $(\mathrm{P}$, units of $\mathrm{Pa}$ ) at a given point in the atmosphere, 
it is possible to calculate the corresponding "molar density" (D, units of $\mathrm{mol} \mathrm{m}^{-3}$ ) at that point. For a detailed discussion of the molar density and its utility for studying the atmosphere, see Refs. [140-142]. However, for brevity, here it suffices to note that the molar density is defined as the number of moles ( $n$, units of mol) per unit volume $\left(\mathrm{V}\right.$, units of $\left.\mathrm{m}^{3}\right)$ and can be calculated using,

$$
\mathrm{D}=\frac{\mathrm{n}}{\mathrm{V}}=\frac{\mathrm{P}}{\mathrm{RT}^{\prime}}
$$

which is a simple re-arrangement of the ideal gas law,

$$
\mathrm{PV}=\mathrm{nRT},
$$

where $\mathrm{R}=8.3145 \mathrm{~J} \mathrm{~mol}^{-1} \mathrm{~K}^{-1}$ is the ideal gas constant. Figure $1 \mathrm{c}$ shows a typical molar density profile versus atmospheric pressure, and Figure $2 \mathrm{c}$ shows the equivalent profile versus altitude/height.

Analysis for a typical weather balloon sonde: Ireland, March 17th, 2016 (LST 12:00h)

(a) Temperature

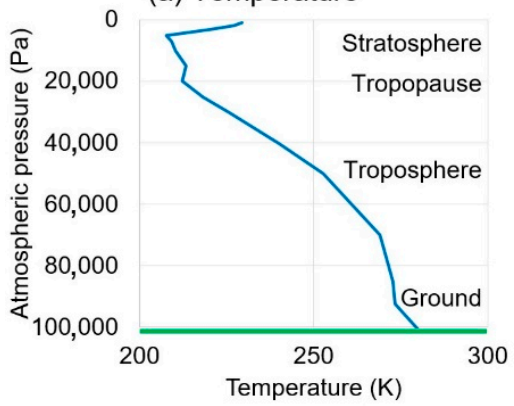

(e) $u$, east/west velocity

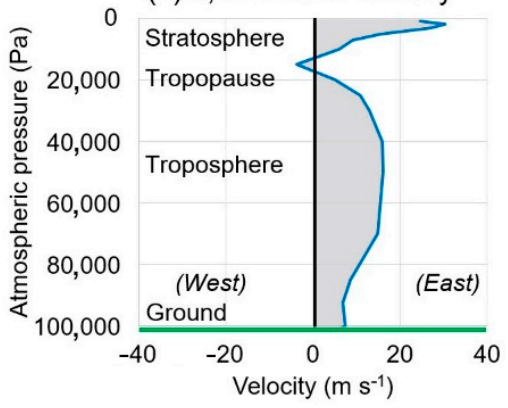

(b) Water vapor pressure

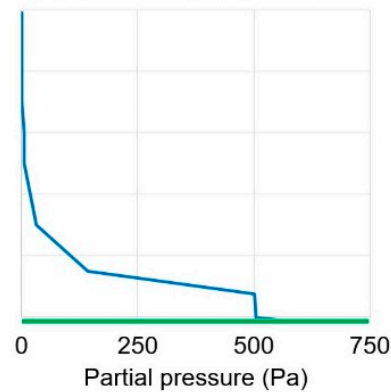

(f) East/west mass flux

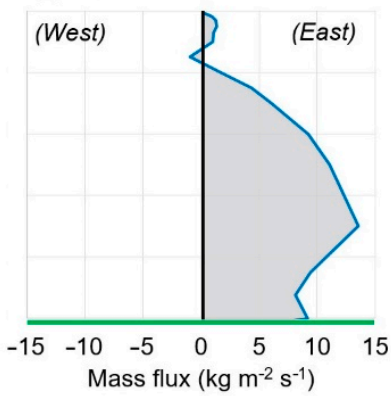

(c) Molar density

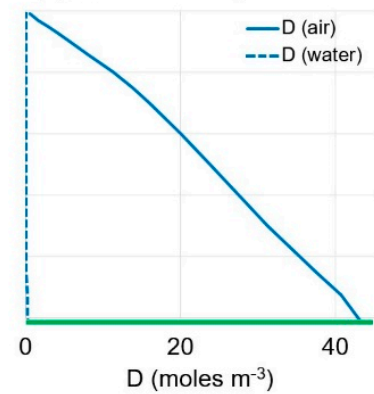

(g) $v$, north/south velocity

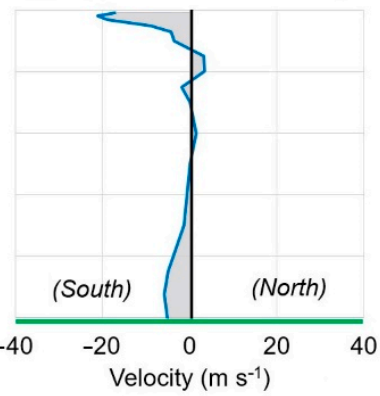

(d) Specific density of air

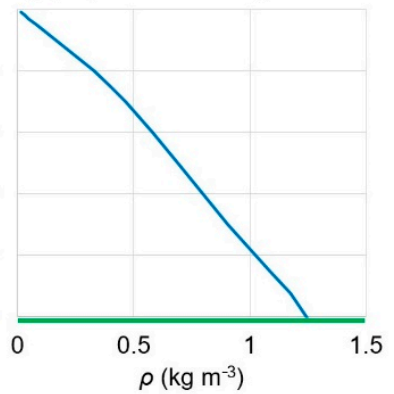

(h) North/south mass flux

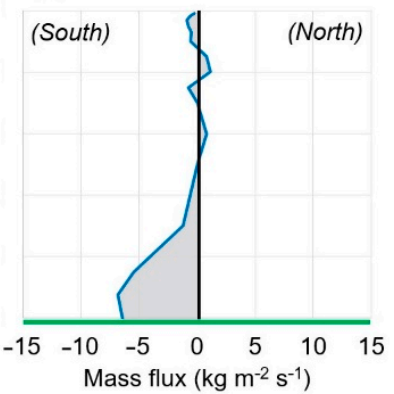

Figure 1. An example of how to compute the atmospheric mass flux based on a typical weather balloon sonde (launched from Valentia Observatory, Ireland) plotted as a function of atmospheric pressure. Panels (a) temperature, (b) water vapor pressure, (c) molar density for both air and water vapor, (d) specific density of air, (e) east-west component of the wind velocity, (f) the corresponding east-west mass flux, (g) north-south component of the wind velocity, and (h) the corresponding north-south mass flux. Directions in brackets indicate the direction from, e.g., "(West)" means "from the west", i.e., "westerly". 
Analysis for a typical weather balloon sonde: Ireland, March 17th, 2016 (LST 12:00h)
(a) Temperature
(b) Water vapor pressure
(c) Molar density
(d) Specific density of air

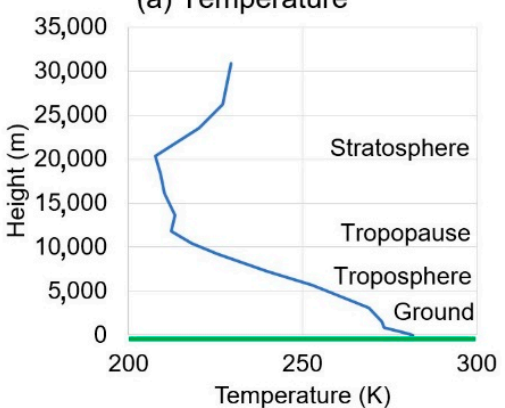

(e) $u$, east/west velocity

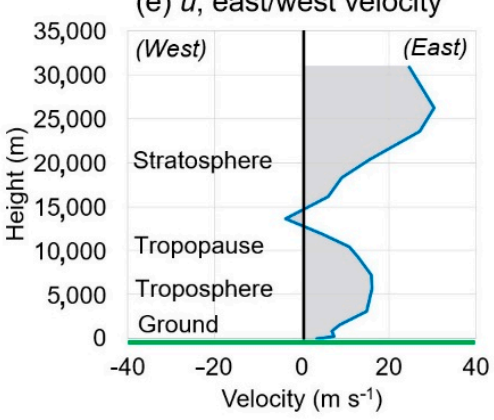

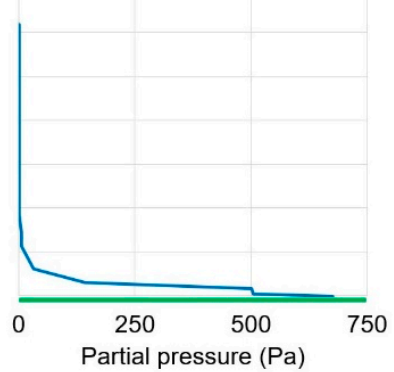

(f) East/west mass flux

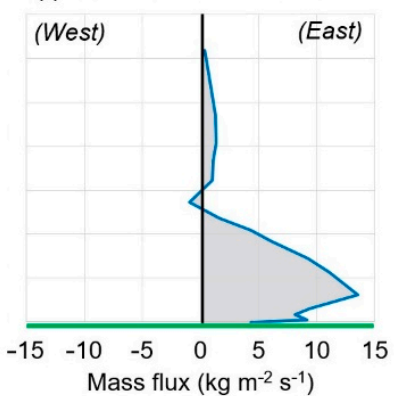

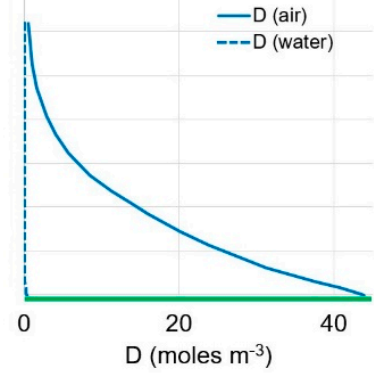

(g) $v$, north/south velocity

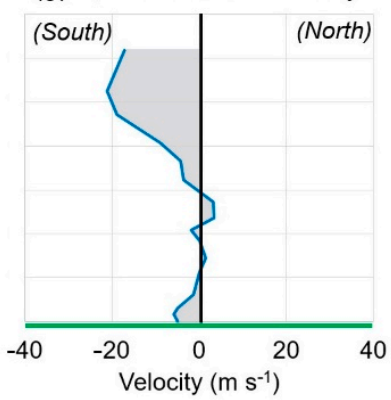

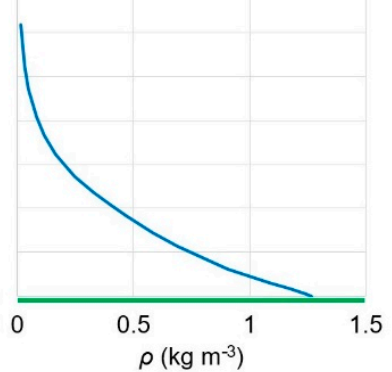

(h) North/south mass flux

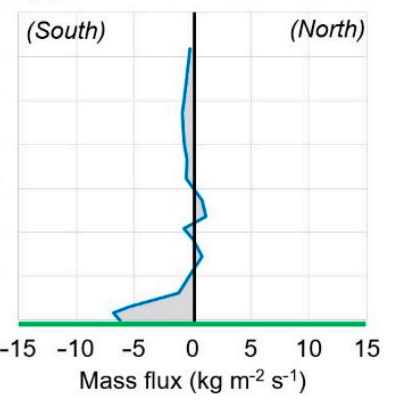

Figure 2. As for Figure 1 but using height/altitude instead of atmospheric pressure as the y-axes. Panels (a) temperature, (b) water vapor pressure, (c) molar density for both air and water vapor, (d) specific density of air, (e) east-west component of the wind velocity, (f) the corresponding east-west mass flux, (g) north-south component of the wind velocity, and (h) the corresponding north-south mass flux. Directions in brackets indicate the direction from, e.g., "(West)" means "from the west", i.e., "westerly".

In terms of atmospheric circulation, a direct estimate of the mass flux is very hard to come by through any other methods unless we carry out in-situ sampling of the atmospheric conditions and fluid flows. However, once the average molecular weight (MW) of the air is known, it is straightforward to convert the molar densities into specific densities $\left(\rho\right.$, units of $\left.\mathrm{kg} \mathrm{m}^{3}\right)$,

$$
\rho=\mathrm{D} \times \mathrm{MW},
$$

The molecular weight of dry air (78\% nitrogen, $21 \%$ oxygen, $1 \%$ argon with some trace gases) is $28.97 \mathrm{~g} \mathrm{~mol}^{-1}$, while that of water is $18.02 \mathrm{~g} \mathrm{~mol}^{-1}$. Therefore, if we assume that the molecular weight of the dry air is constant, equation (3) can be solved once the water fraction of the air is known (although see Ref. [141]). That is, the molecular weight of an air sample is $29.97 \times$ fraction of dry air $+18.02 \times$ water fraction. Different balloon sounding archives often report information on the water component differently. However, most archives will include at least some measure that can be used to calculate the water fraction. Although for the upper atmosphere the absolute humidity is often too low to be measured, and older balloons only provided limited humidity measurements. In our case, using the IGRA dataset, we used equation 10 of Murphy and Koop (2005) [143] to convert the reported dew point depression values into the equivalent water vapor pressures-see Figures $1 b$ and $2 b$.

If the information on the water content is missing for part of a sounding, it can often be extrapolated from the measurements below. However, as can be seen from Figures $1 b$ and $2 b$, above the lower troposphere, the water fraction rapidly decreases. Therefore, for simplicity, in the absence of information on the water content, some researchers may choose to approximate the upper air as being "dry air" to solve Equation (3). If this is done, we recommend that researchers explicitly note they have made this "dry air approximation". 
At any rate, once the specific densities at a given pressure/altitude are calculated-e.g., Figure $1 \mathrm{~d}$ or Figure $2 \mathrm{~d}$ - these can be multiplied by the horizontal zonal (east/west) wind speed, $\left(\mathrm{u}\right.$, units of $\left.\mathrm{m} \mathrm{s}^{-1}\right)$, to yield the horizontal zonal mass flux $\left(\mathrm{f}_{\mathrm{z}}\right.$, units of $\left.\mathrm{kg} \mathrm{m}^{-2} \mathrm{~s}^{-1}\right)$,

$$
\mathrm{f}_{\mathrm{z}}=\rho \times \mathrm{u},
$$

Moreover, similarly by using the horizontal meridional (north/south) wind speed, (v, units of $\left.\mathrm{m} \mathrm{s}^{-1}\right)$, the horizontal meridional mass flux $\left(\mathrm{f}_{\mathrm{m}}\right.$, units of $\left.\mathrm{kg} \mathrm{m}^{-2} \mathrm{~s}^{-1}\right)$ can be calculated,

$$
\mathrm{f}_{\mathrm{m}}=\rho \times \mathrm{v},
$$

These last steps are shown in panels (e)-(h) of Figures 1 and 2.

As a case study of these techniques, in this paper, we have carried out the above calculations (Equations (1)-(5)) for five years of weather balloon soundings (2015-2019) for five stations taken from the North Atlantic region, using soundings taken from the IGRA dataset. We will discuss the station locations and details for our case study below.

\subsection{Sampling of Five Stations Used for This Paper}

The IGRA dataset provides more than half a century of soundings for more than 1000 stations globally [5]. However, as a case study of the use of these techniques for this paper, we selected a small subset of five stations with relatively complete data for the 5-year interval of 2015-2019. We selected this relatively small subset in order to study examples of the results from these techniques in detail. However, we encourage researchers to begin adding the calculations described here to their own research toolbox and to use the same techniques for studying other stations and/or time periods. Moreover, while we use here the IGRA dataset, the same calculations can be applied to other weather balloon soundings datasets, as well as other equivalent datasets such as Zhang et al. (2019)'s aircraft-derived tropospheric profiles [139].

The rationale for our particular station choice was to select five stations located roughly along the same meridional line but covering low to high latitudes to sample the atmospheric circulation regimes nominally described by the Hadley, Ferrell, and Polar circulation cells within the same approximate geographical region, i.e., the European/African North Atlantic sector. Details on these five stations are summarized in Table 1 and the respective locations of these stations in terms of the idealized atmospheric circulation cells are presented in Figure 3.

Although there are multiple European stations with at least two balloons per day for the chosen 5-year period, the available data for north Africa is much more limited. For all of the north African stations available, there were substantial data gaps often spanning several years. However, the two stations we present here had a relatively large coverage and had similar longitudes to the three European stations.

\begin{tabular}{|c|c|c|c|c|c|c|c|}
\hline Country & Location & Station ID & Latitude & Longitude & Elevation & $\begin{array}{c}\text { Years } \\
\text { Covered }\end{array}$ & $\begin{array}{c}\text { Balloons } \\
\text { Available }\end{array}$ \\
\hline Iceland & Keflavíkurflugvöllur & ICM00004018 & $63.9806^{\circ} \mathrm{N}$ & $22.5950^{\circ} \mathrm{E}$ & $52.0 \mathrm{~m}$ & 1946-2021 & 67,193 \\
\hline Ireland & Valentia Observatory & EIM00003953 & $51.9381^{\circ} \mathrm{N}$ & $10.2433^{\circ} \mathrm{E}$ & $23.9 \mathrm{~m}$ & 1949-2021 & 68,495 \\
\hline Spain & Madrid-Barajas & SPM00008221 & $40.4653^{\circ} \mathrm{N}$ & $3.5797^{\circ} \mathrm{E}$ & $631.0 \mathrm{~m}$ & 1950-2021 & 43,864 \\
\hline Morocco & Casablanca & MOM00060155 & $33.5667^{\circ} \mathrm{N}$ & $7.6667^{\circ} \mathrm{E}$ & $56.0 \mathrm{~m}$ & 1949-2021 & 26,290 \\
\hline Mauritania & Nouakchott & MRM00061442 & $18.10^{\circ} \mathrm{N}$ & $15.95^{\circ} \mathrm{E}$ & $2.0 \mathrm{~m}$ & 1941-2021 & 31,687 \\
\hline
\end{tabular}

Table 1. Details on the five North Atlantic weather balloon stations considered for this analysis. 


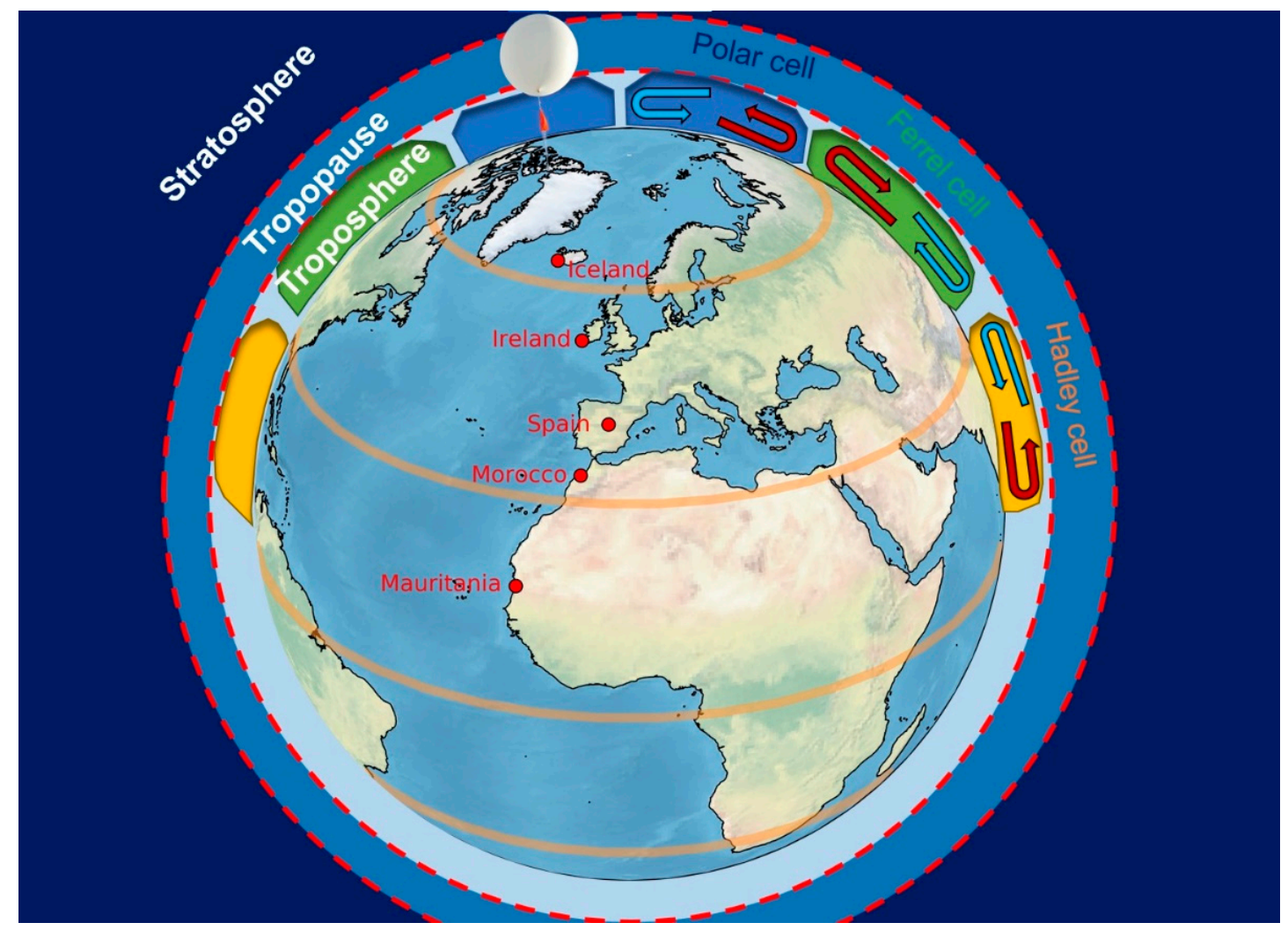

Figure 3. The locations of the five weather balloon stations discussed in this paper in relation to the three idealized atmospheric circulation cells.

\subsection{Wavelet Analysis of the Co-Variability of the Atmospheric Mass Flux Parameters}

For most of the analysis in this paper, we will be describing the results in terms of the basic time series and standard statistics. However, for readers who are interested in more sophisticated frequency analysis, we will also include a preliminary assessment of some of the time series using wavelet analysis.

The wavelet time series analysis program we use here is modified from the standard wavelet analysis program of Torrence and Compo (1998) [144] to analyze and characterize the nature of the time variability of both the N-S and E-W components of the atmospheric mass flux record at several mandated pressure heights of 700,500, 400, 300, 250, and $200 \mathrm{hPa}$. In this analysis, we have used our multi-cross wavelet algorithms to study the simultaneous analysis of the co-variability of those mass fluxes for a selected three widely distributed locations (Iceland, Ireland, and Spain) at these mandated pressure levels which covers most of the troposphere above the boundary layer. The details of the algorithms can be found in Soon et al. (2019) [145], Velasco Herrera et al. (2017) [146], and Soon et al. (2014) [147].

\section{Results and Discussion}

\subsection{Analysis of the 5-Year Time Series}

Figure 4 shows the time series for the meridional (north/south) atmospheric mass fluxes from 2015-2019 for three of the five stations as a function of the height going from ground (top panels), troposphere (middle panels) to tropopause/stratosphere (bottom panels). Figure 5 shows the equivalent results for the zonal (east/west) mass fluxes. We note that the amplitudes of variability are largest within the troposphere and so we use wider $y$-axis scales for the middle panels here.

We first note that the time series at ground level (and within the boundary layernot shown here for simplicity) are often very different from those within the rest of the troposphere and stratosphere. This is particularly apparent for the Iceland station where 
there appears to have been a shift from a prevailing surface southerly (south-to-north) flux in 2015 to a prevailing surface northerly (north-to-south) flux by 2019 (see Figure 4a), and an alternation between a prevailing surface easterly (east-to-west) flux in 2015 to a prevailing westerly (west-to-east) flux in 2016-2017 and back for 2018-2018 (see Figure 5a); however, this apparently did not occur for the rest of the atmosphere.

Since the main focus of this manuscript is to analyze atmospheric circulation patterns, we do not discuss the results for the ground level in much further detail. We merely draw attention to the fact that the observed trends at the ground level can be substantially different from the trends within the free atmosphere. Some of the differences in behavior may be due to surface roughness, turbulence, etc. However, above the boundary layer, the variability in both meridional (Figure 4) and zonal (Figure 5) fluxes is remarkably cohesive.

To convey this, for the middle and lower panels, we have plotted multiple time series taken from different mandated levels throughout the troposphere (middle panels) and tropopause/stratosphere (upper panels). In each case, the visual overlap of the time series for each level with each other is remarkable - the multiple plotted curves in the middle and lower panels all match each other almost exactly. That is, over the 5-year period, the changes in flux at each level in the troposphere above the boundary layer (and equivalently in the tropopause/stratosphere) are broadly in tandem with each other. We have plotted the troposphere and tropopause/stratosphere regions separately since the magnitude of the variability in fluxes tends to be larger in the troposphere region. However, by visually comparing the middle and lower panels, it can be seen that the trends over time are broadly similar. In other words, the bulk of the atmospheric mass at a given location appears to move together in concert.
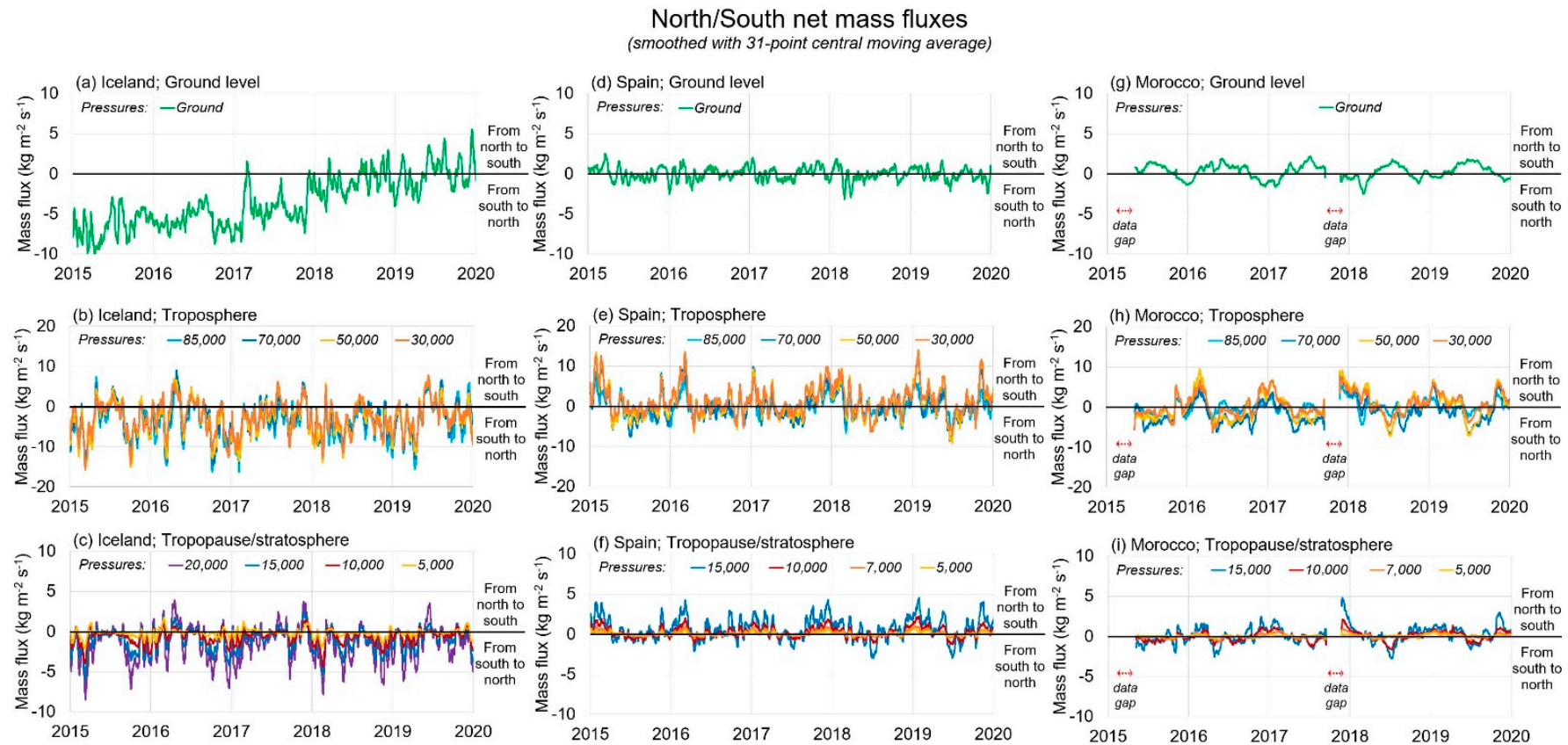

Figure 4. Time series of the meridional (north/south) component of atmospheric mass flux plotted from ground-level (top row), troposphere (middle row) and tropopause/stratosphere (bottom row) for (a-c) Iceland (left column), (d-f) Spain, and (middle column) and (g-i) Morocco (right column). As an aside, we found that the available data records for the north African stations tend to have relatively poor data coverage compared to the European stations. We have indicated the data gaps for Morocco, and stress that the data gaps are even more severe for Mauritania (not shown). 


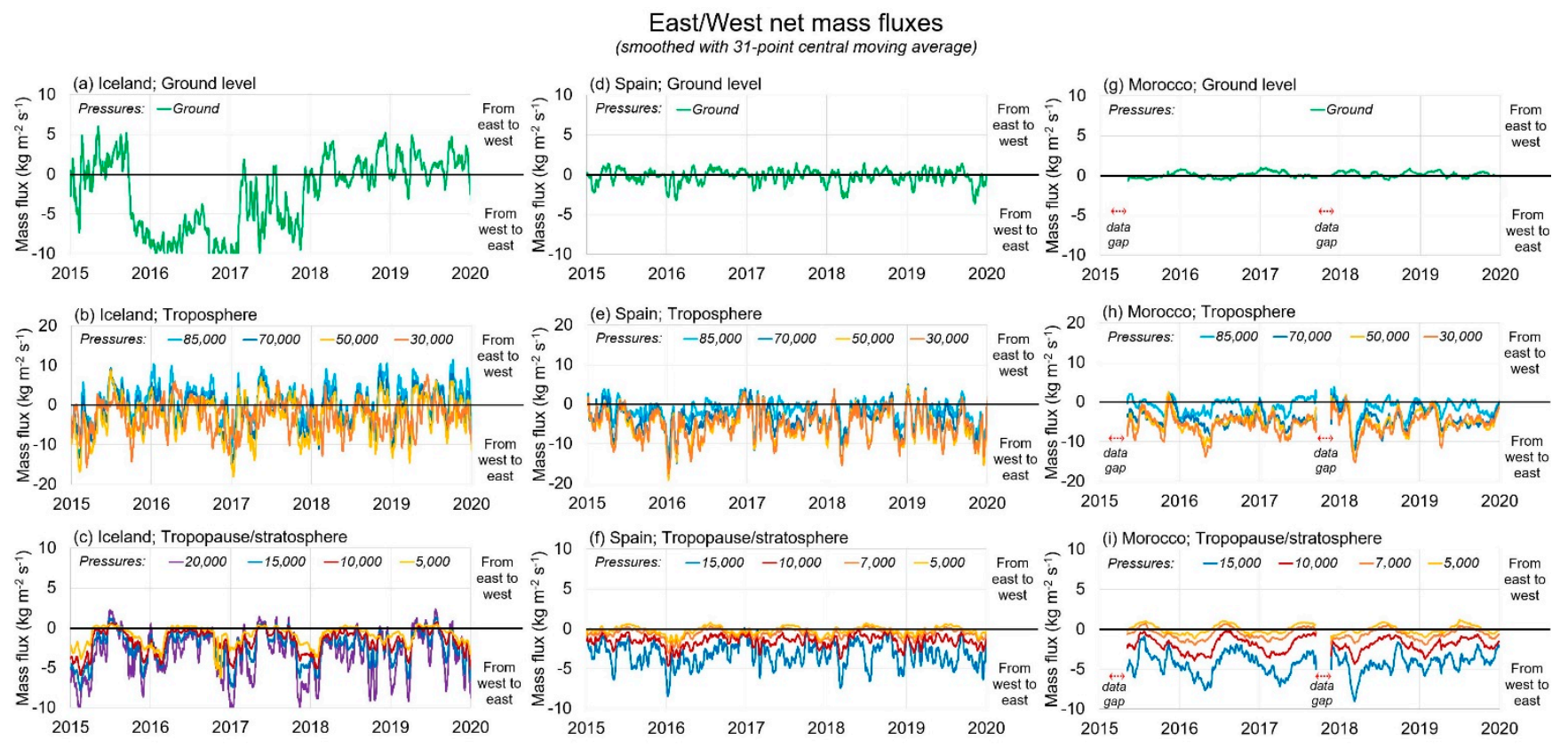

Figure 5. As for Figure 4, except for the zonal (east/west) component of atmospheric mass flux. Again, plotted from ground-level (top row), troposphere (middle row) and tropopause/stratosphere (bottom row) for (a-c) Iceland (left column), (d-f) Spain (middle column), and (g-i) Morocco (right column). As an aside, we found that the available data records for the north African stations tend to have relatively poor data coverage compared to the European stations. We have indicated the data gaps for Morocco, and stress that the data gaps are even more severe for Mauritania (not shown).

As we are a surface-dwelling species, we naturally tend to be more interested in the weather in the atmospheric boundary layer at and near the surface, i.e., the top panels of Figures 4 and 5. However, in terms of atmospheric circulation, we suggest that the remarkable cohesiveness of the changes in direction of the net meridional (Figure 4) and zonal (Figure 5) fluxes between the middle troposphere and lower stratosphere is a key observation. To us, it implies a much greater connectivity between the troposphere, tropopause, and stratosphere (in terms of mass flux) than might be assumed.

\subsection{Analysis of the 5-Year Average Statistics}

The cohesiveness of the changes in mass flux throughout the atmosphere (with the exception of the surface and lower troposphere) is even more apparent from the analysis plotted in Figures 6 and 7. Figure 6 shows the 5-year (2015-2019) time-averaged vertical profile with respect to atmospheric pressure of: (a) the average meridional (north/south) mass fluxes; (b) one standard deviation of the variability; (c) mean meridional wind speed; and (d) the number of balloon profiles available for the five selected stations, i.e., Iceland, Ireland, Spain, Morocco, and Mauritania (from the top row to bottom, respectively). Figure 7 shows the equivalent results for the zonal (east/west) fluxes and wind speeds.

Let us first consider the meridional (north/south) results of Figure 6. As discussed in the introduction, the classical three-cell model of meridional atmospheric circulation makes several idealized predictions about these results. That is, according to the idealized meridional overturning circulation cells (schematically shown in Figure 1), we would expect a net southerly (south-to-north) flux in the lower troposphere/surface for both Iceland ("polar cell") and Mauritania ("Hadley cell"), but a net northerly (north-to-south) flux at the upper troposphere. Meanwhile, for the other three stations (Ireland, Spain, and Morocco), we would expect the exact opposite since they should be within the northern hemisphere Ferrel cell. In each case, the net direction of the flux should in theory reverse at some point in the mid-troposphere. The three-cell model does not explicitly predict a net meridional flux within the mid-troposphere. Moreover, the cells are currently proposed to 
be confined to the troposphere (although the existence of the tropopause/stratosphere was not discovered until the early 20th century [148]).

North/South net mass fluxes

(average for 2015-2019 period)
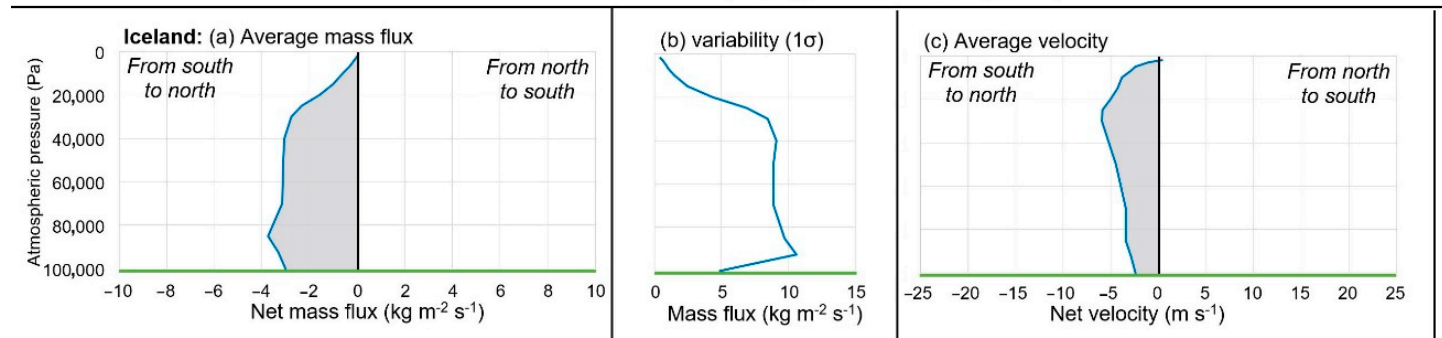

\begin{tabular}{l} 
(d) Available data \\
Stratosphere \\
Tropopause \\
Troposphere \\
Ground \\
\hline 100020003000400
\end{tabular}

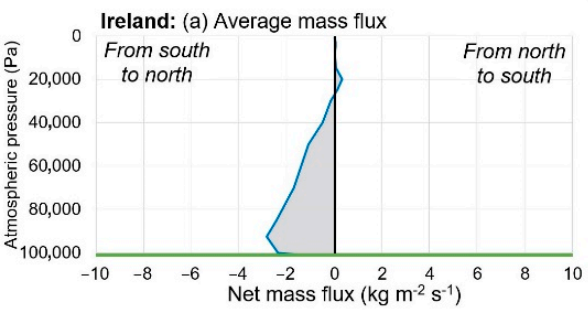

(b) variability $(1 \sigma)$

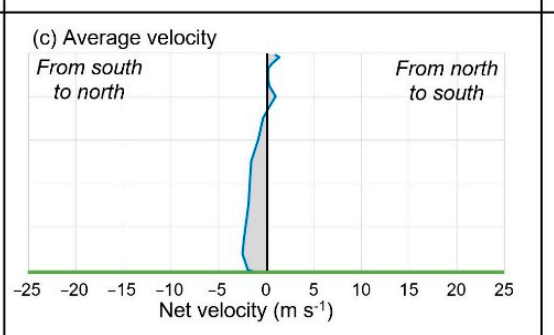

Available data

Tropopause
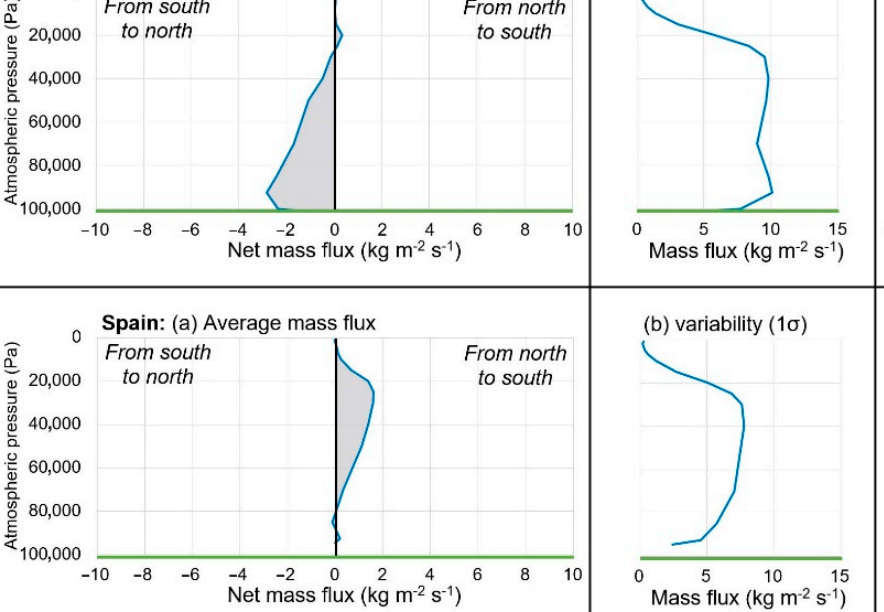

(b) variability $(1 \sigma)$

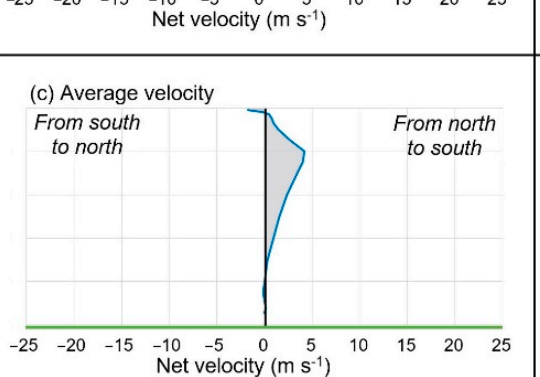

Ground

1000200030004000
Number of balloons

(d) Available data

Stratosphere

Tropopause

Troposphere

Ground

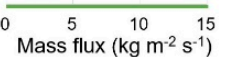

(c)

(b) variability $(1 \sigma)$

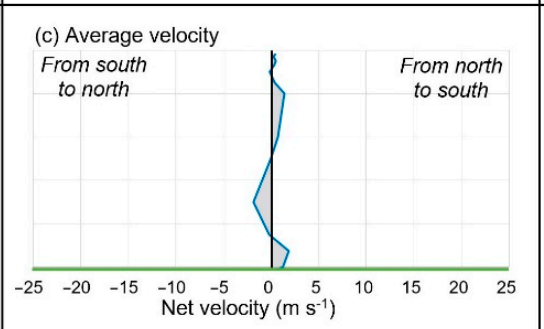

(d) Available data
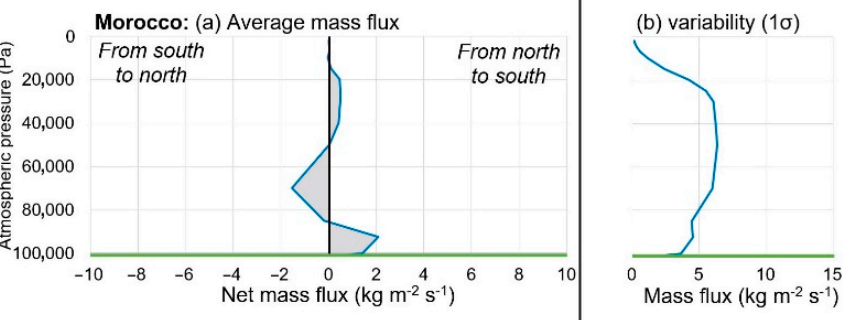

Stratosphe

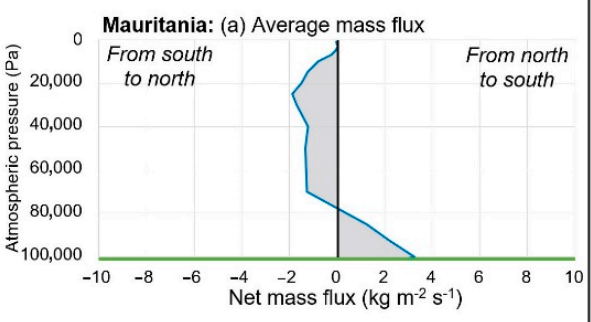

(b) variability $(1 \sigma)$

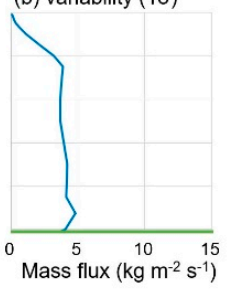

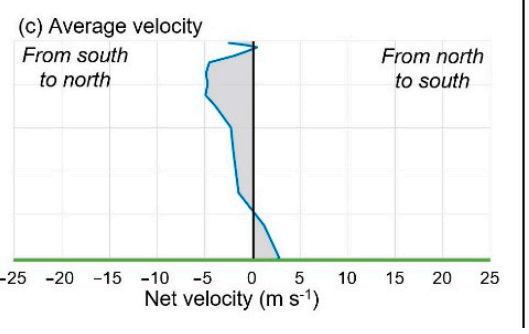

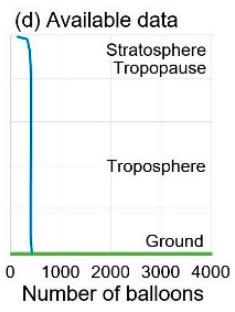

Figure 6. Mean vertical profile of mass fluxes and mean vertical profile of wind speed for the North-South atmospheric circulation component from ground to stratosphere. The averages are obtained over the 2015-2019 interval covering all five stations (Iceland, Ireland, Spain, Morocco, and Mauritania) within the three circulation cells paradigm of atmospheric physics. (a) average mass flux from south to north; (b) variability; (c) average velocity from south to north (d) available date. 
East/West net mass fluxes

(average for 2015-2019 period)
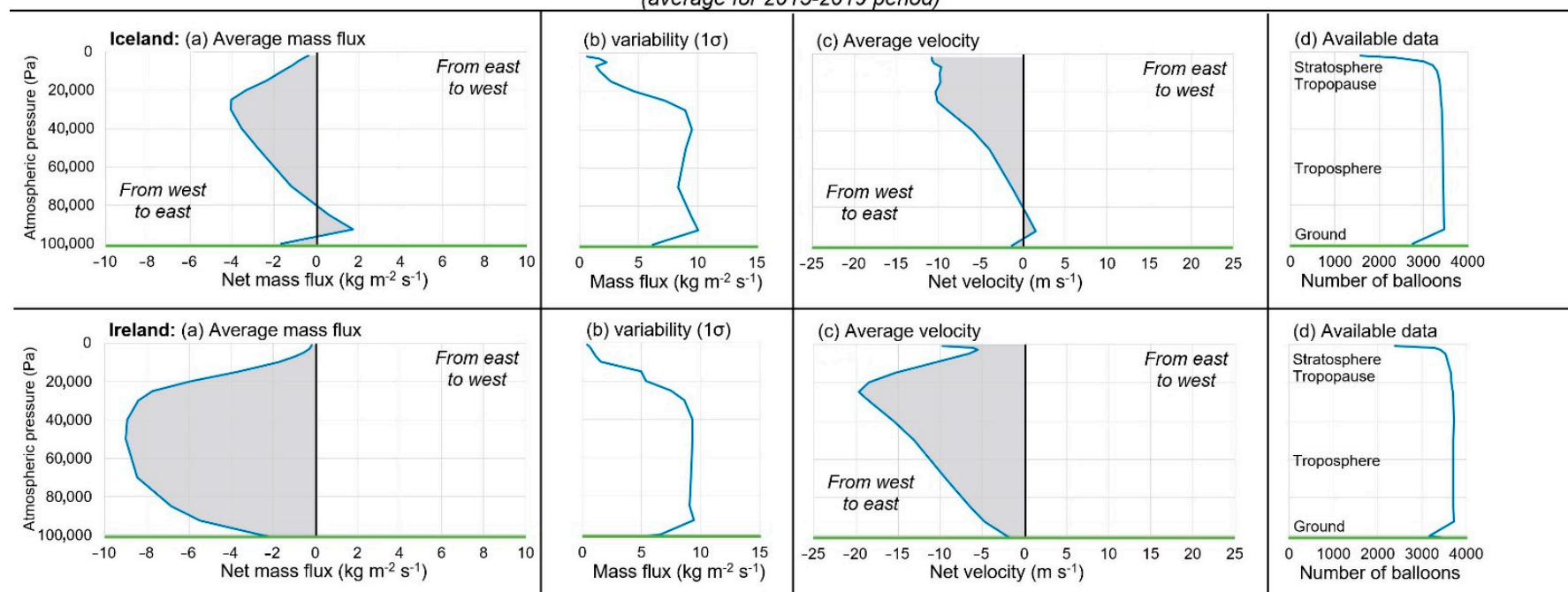

(d) Available data

Stratosphere
Tropopause
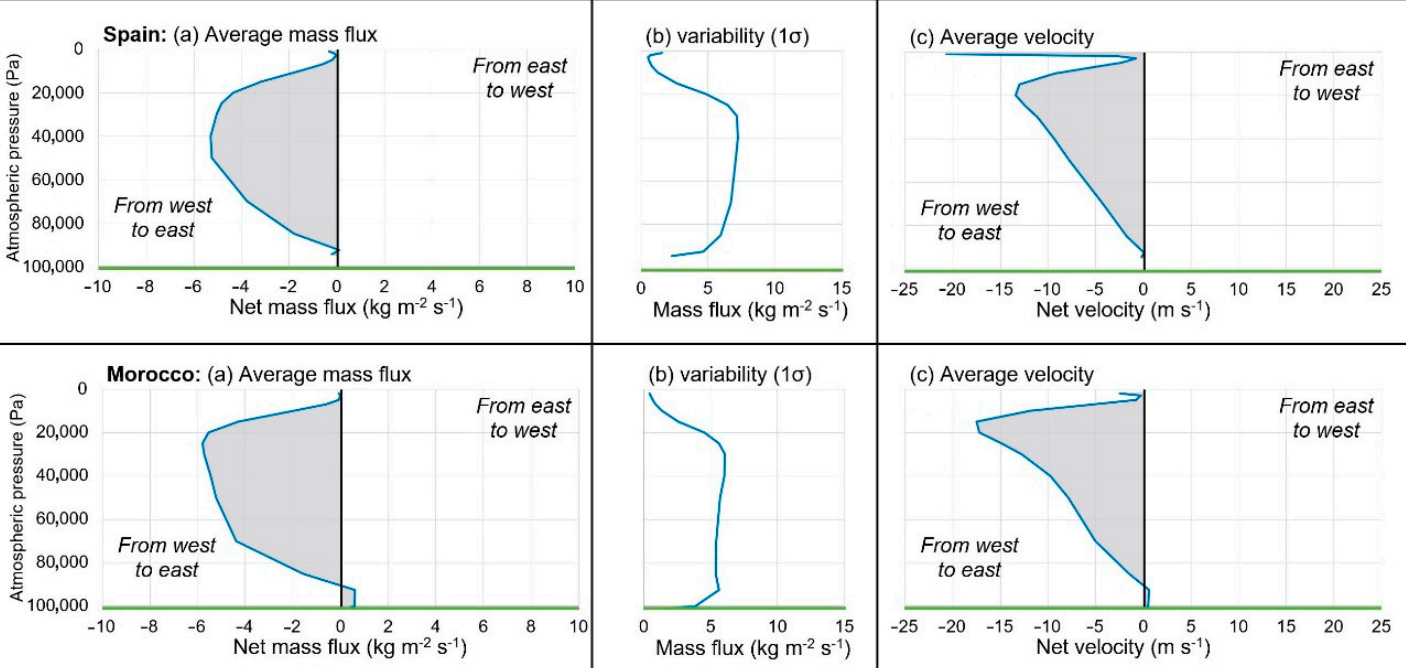

$0 \quad 1000200030004000$

Ground umber of balloons
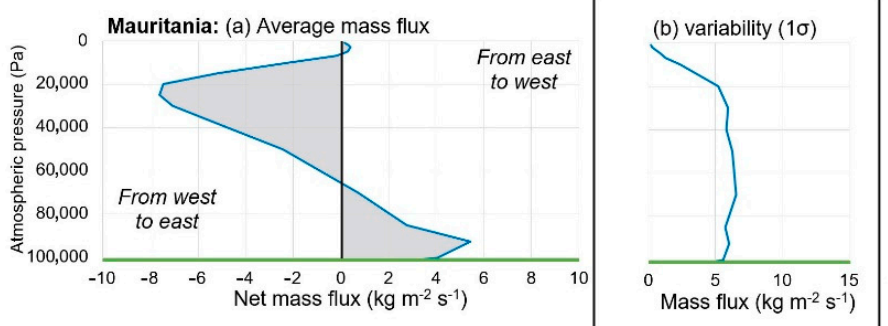

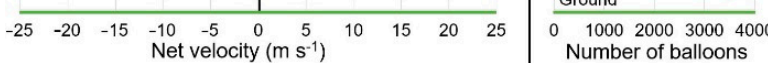

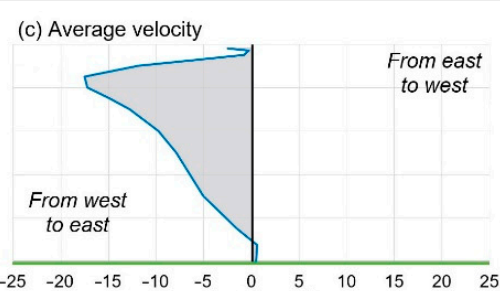

(d) Available data

(d) Available data

Stratosphere
Tropopause

Tropopause

Troposphere

(6)

Stratosphere
Tropopause

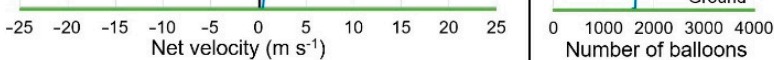

\begin{tabular}{l|l} 
(c) Average velocity & (d) Available data
\end{tabular}

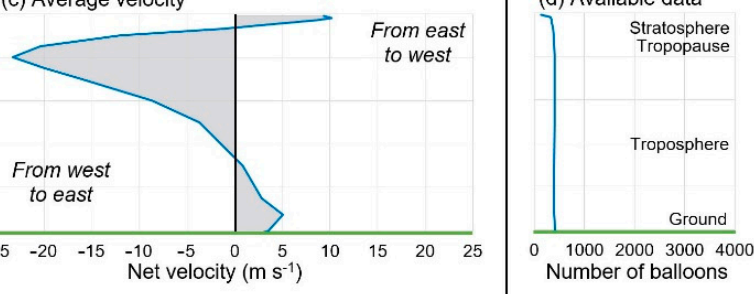

Figure 7. As for Figure 6, except for the East/West atmospheric circulation components from ground to stratosphere. The averages are obtained over the 2015-2019 interval covering all five stations (Iceland, Ireland, Spain, Morocco, and Mauritania) within the three circulation cells paradigm of atmospheric physics. (a) average mass flux from south to north; (b) variability; (c) average velocity from south to north (d) available date.

How do these predictions compare with our results? For four of our stations (Iceland, Ireland, Spain, and Morocco), we do not see any evidence of the expected cell-like patterns. Moreover, with the possible exception of Ireland where there is a change from southerly to northerly flux near the tropopause region, it is hard to identify any clear transition from a "tropospheric circulation" to the tropopause/stratosphere. That is, for these four stations at least, the results appear inconsistent with those expected for the polar and Ferrel cells. This appears to echo the arguments of the "pro-eddy camp" described in the introduction. On the other hand, there is some partial support for the existence of a Hadley cell from the Mauritania results in that the net flux is indeed southerly (south-to-north) for the 
lower troposphere and northerly (north-to-south) for the upper troposphere, as predicted. Therefore, perhaps Holopainen was correct in his suggestion that the extratropics are dominated by eddies ("Rossby regime") while the tropics are better described by the cellular model ("Hadley regime") [37,38].

That said, we suggest that even for Mauritania, these results are only partially consistent with the Hadley cell for at least two reasons: (1) the current depiction of the Hadley cell implies that it is a tropospheric circulation, yet the net northerly flux continues well into the tropopause/stratosphere. (2) The data implies a net northerly flux throughout most of the troposphere, rather than a strict division between an upper and lower flow. On this latter point, we note that many of the studies in the 1960s based on meridional wind speeds had a similar problem and had to apply post hoc "mass balance adjustments" to the data to obtain the predicted net-zero meridional velocity for the mid troposphere $[35,39,40]$. We will describe additional problems for the use of the Hadley cell notion for Mauritania later. On the other hand, we caution that the available data for Mauritania during this 5-year period is relatively small-compare panel (d) for it to the other stations, and so some of these inconsistencies with the expected results might be due to poor data availability.

Let us now turn to the zonal (east/west) results of Figure 7. For most of the data, the net zonal fluxes are both larger in magnitude and more consistent than for the meridional fluxes. The vertical profiles for all five stations are dominated by prevailing westerly (westto-east) mass fluxes. A notable exception is the strong easterly (east-to-west) surface flux at Mauritania. This coincides with the "trade winds" phenomenon but seems to be confined to the lower troposphere. There is also a slight surface net easterly flux for Morocco and also for part of the lower troposphere in Iceland. However, overall, most of the zonal fluxes for this cross-section of the North Atlantic region are dominated by strong westerly (west-to-east) mass fluxes.

One additional point to note about the mass fluxes in both Figures 6 and 7 is how they compare and contrast to the equivalent wind speeds (velocities). Because the specific density of the atmosphere decreases with height, the shapes of the mass flux vertical profiles are different from the equivalent wind velocity profiles-panels (a) and (c) respectively. Therefore, a small change in net velocity near the surface can often lead to a greater change in the net mass flux than a large change in the upper atmosphere. However, we suggest that the mass fluxes are more relevant for understanding the mass transport of the atmospheric circulation patterns than the raw velocities.

Figure 8 shows an alternative approach to describing the data. For each station, we have calculated the correlation coefficient $(r)$ between the daily mass fluxes at each mandated level and that at 50,000 $\mathrm{Pa}(500 \mathrm{hPa})$ over the entire 5-year period. $\mathrm{r}$, can vary between 1 (exactly correlated) to 0 (completely uncorrelated) to -1 (exactly anti-correlated). The panels on the left show the results for the meridional (north/south) mass fluxes, while those on the right show the zonal (east/west) results. 


\section{Correlations in mass fluxes at $\mathrm{P}($ level $)$ and $\mathrm{P}(50000 \mathrm{~Pa})$}

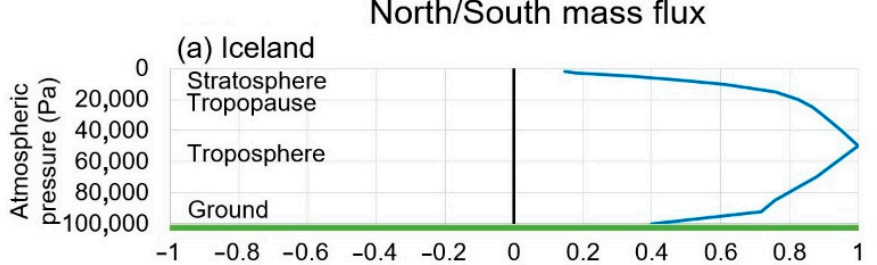

(b) Ireland

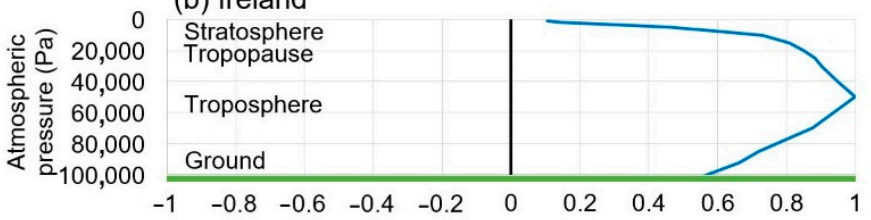

\section{(c) Spain}

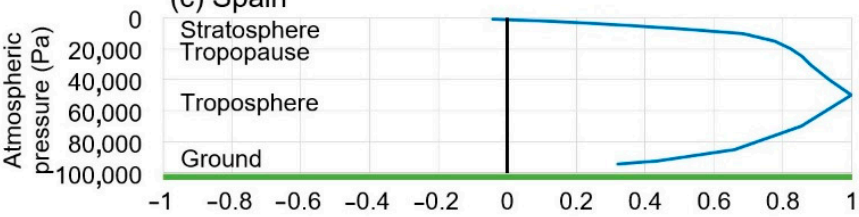

(d) Morocco

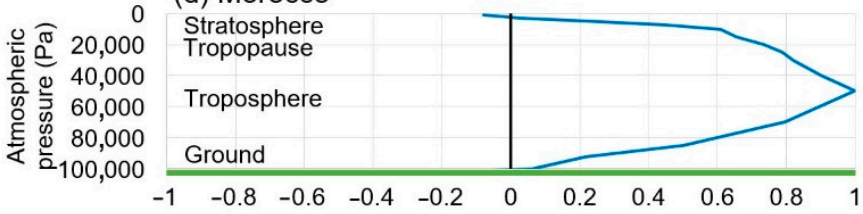

(e) Mauritania

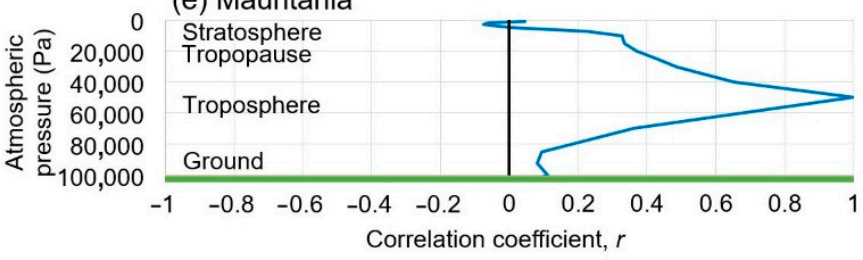

\section{East/West mass flux}

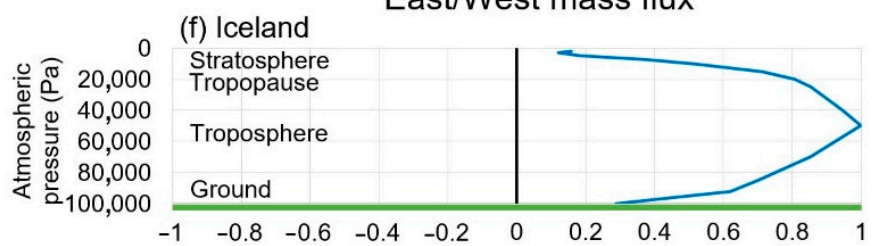

(g) Ireland

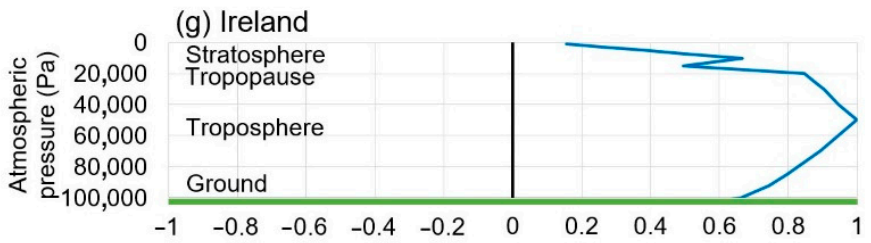

(h) Spain

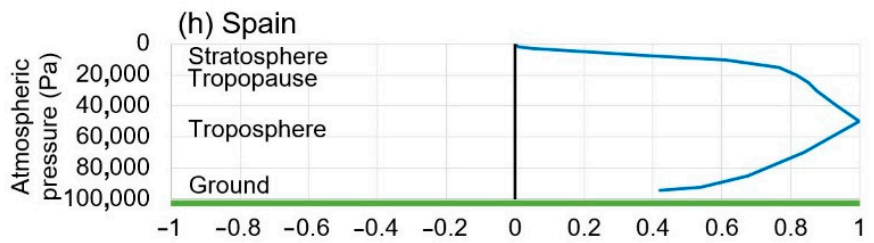

(i) Morocco

Stratosphere

Tropopause

Troposphere

Ground

(j) Mauritania

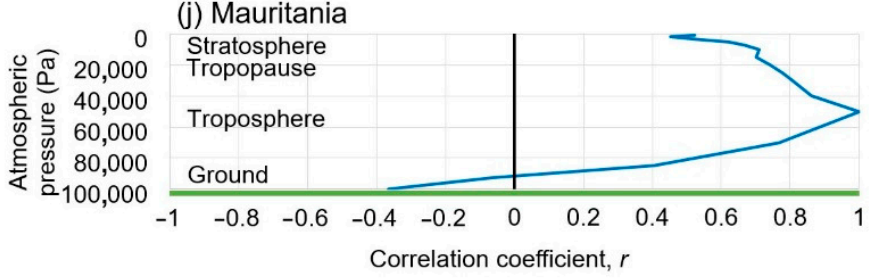

Figure 8. Vertical profiles of correlations of (a-e) North-South and (f-j) East-West components of atmospheric mass fluxes with the value at mid-troposphere of 50,000 $\mathrm{Pa}(500 \mathrm{hPa})$ for all five stations.

Note that the correlations with 50,000 Pa are self-correlations, and therefore exactly 1 , by definition. Unsurprisingly, the correlations with the levels close to P (50,000 Pa) are also close to 1 . However, it is noteworthy that with the exception of a few of the highest points in the mid-stratosphere and the surface zonal fluxes for Mauritania-Figure 8j-all of the correlations are greater than zero.

If the three-cell model of meridional circulations were dominant, we might expect that the mass fluxes in the upper troposphere would be anti-correlated with those in the lower troposphere, i.e., the upper and lower flows would be in the opposite direction. We do not find this-Figure 8a-e. Even for Mauritania, which we showed earlier was partially consistent with the idea of a Hadley cell, the correlations remain greater than zero throughout the entire troposphere and tropopause. Therefore, we suggest that the results for Mauritania are only partially consistent with that expected for a Hadley cell.

In contrast, for the zonal fluxes, we do see a clear anti-correlation of the near-surface fluxes for Mauritania with the rest of the atmosphere. This is as expected from our observations from Figure 7 that the net zonal mass fluxes for Mauritania are easterly near the surface ("trade winds"), but westerly for most of the atmosphere.

The same approach could be repeated for a different mandated level, e.g., the surface, a level in the lower troposphere or in the stratosphere, and this can yield slightly different perspectives. Chiefly, the location of the $r=1$ self-correlation point will move to whatever 
level is chosen, but such analysis can also potentially provide other insights. However, for brevity, we only report the results for $50,000 \mathrm{~Pa}$, which represents the mid-point of the atmosphere in terms of mass, i.e., the point in the mid-troposphere where half of the mass of the atmosphere is above and half is below.

\subsection{Preliminary Frequency Analysis of the Time Series}

We next perform some exploratory frequency analysis of the time series described above in terms of a similar wavelet analysis to that used by some of us elsewhere [145-147]. This type of frequency analysis can often be insightful when analyzing multiple related time series that cover the same period. For instance, it can potentially help identify covariability between the time series and/or any quasi-periodic behaviors within different datasets.

Clearly, since this is just a case study of five stations for five years, the results discussed below are necessarily limited in both geographical coverage and the timescales covered. However, the use of wavelet-based frequency analysis is becoming increasingly popular for studying hydroclimatic time series $[84,87,91,92,103-105,144,146,147,149,150]$. Often the variabilities of these time series are compared with metrics of potential climatic drivers, including solar activity metrics $[84,87,91,92,103-105,149,150]$, anthropogenic forcings $[149,150]$ and atmospheric circulation indices such as NAO, ENSO, QBO, etc. [84,91,92,150]. A major advantage of this type of analysis is that it can be applied to different timescales based on the resolution and length of the time series being analyzed. In our case, we are analyzing a twice-daily time series spanning five years ( 3600 data points per station). Other studies have applied similar approaches to lower resolution (e.g., annually resolved) proxies with much longer time spans, e.g., multiple centuries $[87,104]$. In principle, the results from long time span but low-resolution time series can be combined with those from shorter time span but higher-resolution time series. Therefore, we want to demonstrate how the use of wavelet-based frequency analysis can also be applied to mass flux calculations, and to give the reader a preliminary idea of what the results can look like with this case study as an example.

Even for this relatively small case study, there are multiple combinations of time series that could potentially be analyzed in this way. For example, the co-variability of the time series for each mandated level for a given station could be analyzed. However, for brevity, we have chosen here to simply compare the time series from the same mandated level $(50,000 \mathrm{~Pa}$ or $500 \mathrm{hPa})$ for the three of our five stations that have almost complete data coverage for the 5-year period, i.e., Iceland, Ireland, and Spain. (An alternative approach might be to consider all five stations but only analyze the periods of overlap. However, as discussed earlier, the Mauritania time series, in particular, has a lot of missing data.)

The results of our multi-cross wavelet are presented in Figures 9 and 10, where the panels are as follows: (a) the time series we analyzed (top center panel), (b) the timeaveraged global wavelet period (left panel), (c) the time-frequency cross wavelet power for the multiple time series (center panel), and (d) the amplitude (right-hand scale) of the cross-wavelet power. Note the colors in the central panels show the time evolution of these potential periodicities (red colors at a given time indicate a high power for the corresponding periodicity).

Figure 9 shows the results for the meridional (north/south) mass fluxes, while Figure 10 shows the zonal (east/west) results. We first note that in each case, the 50,000 Pa time series for the three locations do not exactly overlap with each other on a short-term basis. That is, the time series for Iceland (black), Ireland (blue), and Spain (yellow) are clearly different. Nonetheless, the wavelet analysis identifies many commonalities between the series and some strong peaks associated with particular periodicities.

The most prominent peak is a quasi-annual periodicity of 0.96 years which is present for both the meridional (Figure 9) and zonal (Figure 10) fluxes. However, there are also several other smaller peaks that might also potentially have some climatic significance. For the meridional fluxes, there is a moderate-sized peak at around 1.44 years and several 
smaller peaks. For the zonal fluxes, the peak at around 1.44 years is missing, but there are several moderate peaks clustered between around 0.22 years and 0.5 years. Possibly coincidentally, several of the small peaks for the meridional fluxes have similar periodicities.

We stress that in this section we have only analyzed five years of data at a fixed isobar for three locations. Therefore, we do not want to draw too many conclusions from the apparent periodicities from this analysis-although the quasi-annual periodicity of 0.96 years appears to be quite pronounced and particularly intriguing. While nearly annual, it is not exactly annual. Therefore, it is probably not directly due to the annual orbit of the Earth around the Sun but possibly has some other origin.

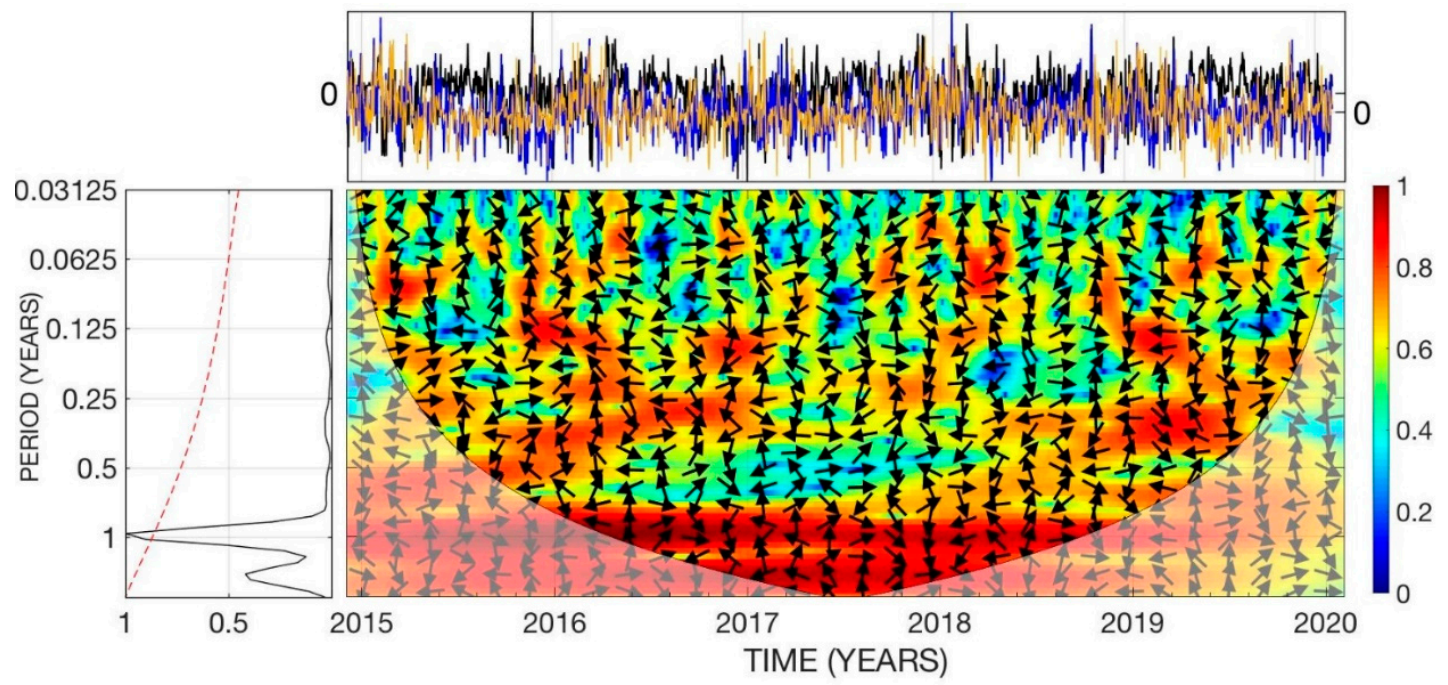

Figure 9. A time-series analysis N-S mass flux for 3 selected stations (Iceland-black; Ireland-blue; Spain-yellow) studying the interconnection of the mass fluxes at six tropospheric levels (700, 500, 400, 300, 250, and $200 \mathrm{hPa}$ ) adopting the multi-cross wavelet algorithm introduced and described in Soon et al. (2014) [147] and Velasco Herrera et al. (2017) [146]. We note that the two data records for Morocco and Mauritania are less well sampled and recorded and hence in this paper, we have decided to post-pone the full and complete study using all five stations.

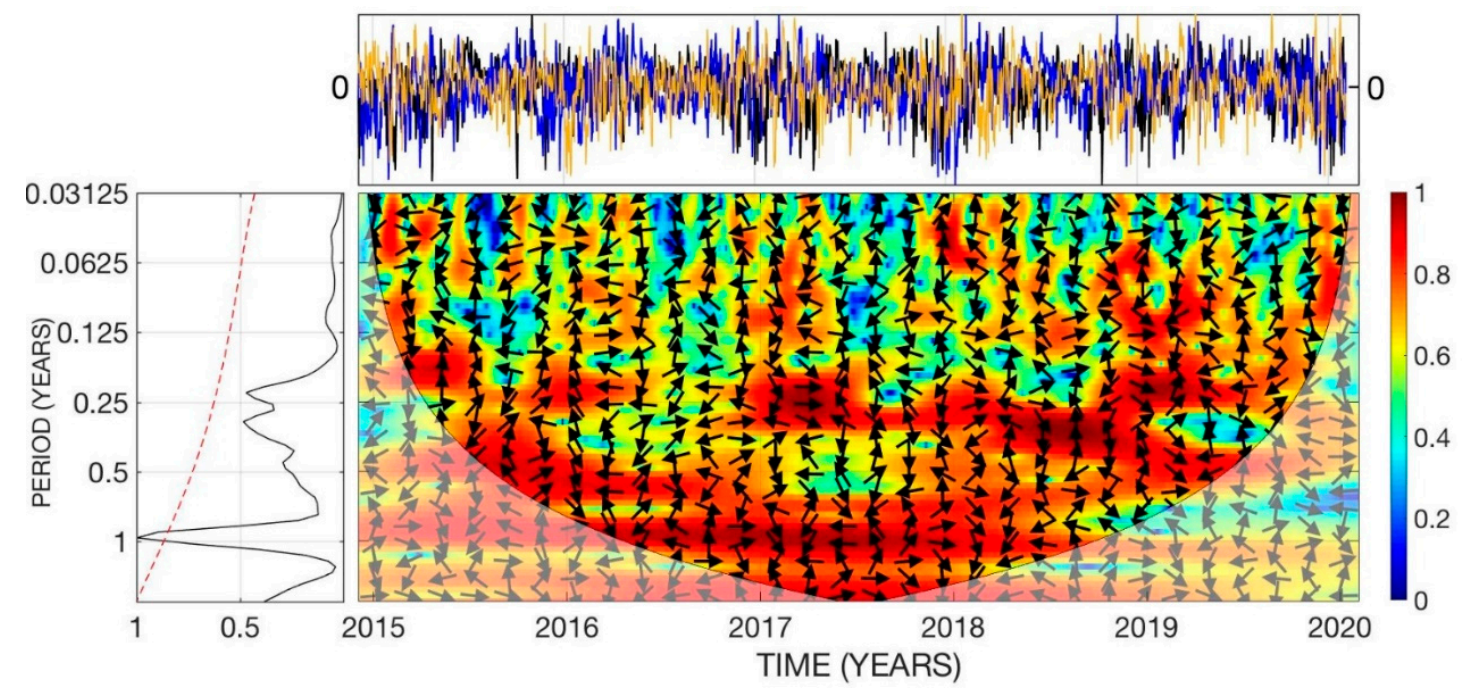

Figure 10. A time-series analysis E-W (right column) mass flux for 3 selected stations (Iceland—black; Ireland-blue; Spain-yellow) studying the interconnection of the mass fluxes at six tropospheric levels (700, 500, 400, 300, 250, and $200 \mathrm{hPa}$ ) adopting the multi-cross wavelet algorithm introduced and described in Soon et al. (2014) [147] and Velasco Herrera et al. (2017) [146]. We note that the two data records for Morocco and Mauritania are less well sampled and recorded and hence in this paper, we have decided to post-pone the full and complete study using all five stations. 
Instead, we want to highlight how the application of these wavelet analyzes to the mass flux data could potentially reveal important insights into atmospheric circulations. In particular, if quasi-periodic patterns in the mass fluxes for a given region (or regions via "teleconnections") can be identified, this could help our understanding of climatic variability and/or weather patterns. Indeed, several quasi-periodic regional behaviors have already been established as climatically important across a range of time scales. For example, the Madden-Julian Oscillation (MJO) is a regionally important tropical atmospheric phenomenon with a quasi-periodicity of 30-60 days (0.08-0.16 years) [65]; the Quasi-Biennial Oscillation (QBO) is an important oscillation in the net direction of equatorial stratospheric zonal winds with a quasi-periodicity of 27-28 months (2.2-2.3 years) [42]; El Niño-Southern Oscillation (ENSO) has a quasi-periodicity of 2-8 years [56-62].

With that in mind, it might be worth considering some of the potential origins for quasiperiodic climatic phenomena-whether localized or covering a large geographical region. One likely candidate for climatic variability is of course solar variability-for an extensive discussion on this topic, we recommend our recent review, Connolly et al. (2021) [76]. However, there are many other factors that could play a role, especially when dealing with regional climatic variability (as opposed to global climatic variability). Well-known candidates include potential couplings between the oceans and atmosphere $[57,71,72]$, geographical differences in topology (e.g., mountains versus plains), and land/ocean differences [66].

We would also like to draw the reader's attention to the possible role of the gravitational effects from so-called "short-term orbital forcing" (STOF) [151]. The climatic significance of STOF has been largely unappreciated until recently, but we note that it offers plausible candidates for explaining specific quasi-periodicities. In terms of the apparent periodicities in Figures 9 and 10, several potential candidates can be found in the lists of Cionco et al. (2021) [151]. For example, periodic perturbations affecting the instantaneous solar irradiance, irradiation integrated quantities, and even tidal influences (ordered following its gravitational importance) can be observed for the peak in meridional flux around 1.44 years (e.g., 1.46 years, order 88 ) and the peaks around 0.96 years for both meridional and zonal flux, (e.g., 0.94 years, order 63; 0.97 years, order 75). Periodicities similar to several of the other peaks observed in the spectra of Figures 9 and 10 can also be found, e.g., the peaks at 0.57 years in zonal and 0.542 years for meridional are similar to Cionco et al.'s 0.55 years (order 4) peak; Cionco et al.'s 0.32 year (order 27) peak could potentially be related to the peaks at 0.34 years in meridional and 0.30 years in zonal; the 0.07 year (order 19) peak could potentially be related to the observed peaks at 0.076 years in meridional or 0.06 years in zonal flux.

\subsection{Applicability of These Techniques to Investigating Links between Atmospheric Circulations and Solar Activity as Well as Other Climatic Drivers}

The exploratory analysis in this case study was confined to five years of data for five stations taken from the North Atlantic sector. However, it is hoped that the demonstration of the new techniques described in this paper will inspire other researchers to apply these techniques to more stations and/or different time periods.

As discussed earlier, the IGRA dataset which we used here is a particularly useful starting point for future research in that it provides balloon soundings for more than 1000 stations with some records beginning in the early 20th century $[3,5,77]$ although we note that the resolution and the data availability from a balloon sounding has improved dramatically in recent decades. However, the calculation of mass fluxes could also be applied to other similar datasets, provided they provide simultaneous measurements of temperature, pressure, wind velocities, and ideally water content measurements.

At any rate, we want to emphasize the relative simplicity of these mass flux calculations. Until now, most of the research into atmospheric circulations and climate variability has tended to focus on the temperature, precipitation, and/or pressure fields, e.g., $[73,76,84,87,90,91,103-106,150]$. However, we suggest that mass fluxes represent a more direct measure of atmospheric circulations. As discussed in Section 1.2, most of the 
early research into atmospheric circulations which used weather balloons focused on the wind velocities e.g., $[10,11,15,24,29,32,43,44,56]$. Yet, as can be seen from Figures 1 and 2, while related, these measurements provide a quite different view of atmospheric circulations than the equivalent mass flux calculations.

Moreover, the mass flux calculations can be used to directly describe mass transport patterns. That is, the "averages of horizontal (... ) motion of air over time and space as well as temporal and spatial deviations from the average conditions" which Knox and Knox (2017) define as the "general circulation of the atmosphere ( . . ) in its most basic sense" [2]. Therefore, we suggest that a better understanding of atmospheric circulation in terms of mass fluxes should provide a more direct description of what we mean by "atmospheric circulation".

As mentioned in Section 1.3, several studies have already argued for solar signals in multiple atmospheric circulation indices which are less direct, including both the NAO [72,81-87] and NAM [88], i.e., indices that are directly relevant to the North Atlantic region studied here. Therefore, we expect that mass flux-based descriptions of atmospheric circulations should help researchers more accurately identify potential "links between solar activity and atmospheric circulation", i.e., the theme of this special issue. Similarly, it should help identify potential links between atmospheric circulation and other climatic drivers, including changes in oceanic circulation patterns [152-154] and anthropogenic factors $[149,150]$.

\section{Conclusions and Recommendations}

Much of the recent research into studying atmospheric circulation patterns has tended to rely on either semi-empirical datasets (i.e., reanalyses) or modeled output (i.e., global climate models). Therefore, several researchers have emphasized the importance of developing better metrics for investigating atmospheric circulations directly from empirical observations [117,123-128]. In this paper, we showed how the application of several relatively simple calculations to the basic measurements from a standard weather balloon sounding yields a vertical profile of the horizontal atmospheric mass fluxes.

To demonstrate how these techniques can be applied to real-world data, we carried out a case study for five stations taken from the North Atlantic sector using five years of weather balloon readings (2015-2019). The results from these stations demonstrated a remarkable cohesiveness in the changes in direction of the net meridional and zonal fluxes between the middle troposphere and lower stratosphere. This suggests a much greater connectivity between the troposphere, tropopause, and stratosphere (in terms of mass flux) than might be assumed.

We suggest that the extension of the techniques described here to other stations and time periods could provide a powerful new empirical tool for analyzing regional and even global atmospheric circulation patterns. Therefore, we recommend this as a new tool for researchers interested in studying atmospheric circulation.

We suggest that a mass flux-based understanding of atmospheric circulation patterns could potentially lead to a deeper understanding of the causes of variability in atmospheric circulations, including those arising from solar activity, changes in oceanic circulation, anthropogenic factors, etc.

As a final comment, we note that weather balloons only record the horizontal wind velocities, and therefore the techniques described here only provide the horizontal mass fluxes. However, many balloon soundings also record the flotation velocities, i.e., the rate of ascent of the balloon. If these flotation velocities could be used to infer the relative vertical wind velocities, then the calculations described here could be similarly applied to derive the relative vertical mass flux values.

Author Contributions: Conceptualization, methodology and validation, M.C., R.C. and W.S.; formal analysis, M.C., R.C., W.S., V.M.V.H. and R.G.C.; writing-original draft preparation, M.C., R.C. and W.S.; writing-review and editing, M.C., R.C., W.S., V.M.V.H., R.G.C. and N.E.Q. All authors have read and agreed to the published version of the manuscript. 
Funding: The authors R.G.C. and N.E.Q. acknowledge the support of the grant PID-5265TC of National Technological University of Argentina. R.C. and W.S. received financial support from the Center for Environmental Research and Earth Sciences (CERES), http:/ / ceres-science.com/ (accessed on 10 October 2021), while carrying out the research for this paper. The aim of CERES is to promote open-minded and independent scientific inquiry. For this reason, donors to CERES are strictly required not to attempt to influence either the research directions or the findings of CERES.

Acknowledgments: We thank the editor and two reviewers for their constructive feedback. We are grateful to Imke Durre et al. at NOAA NCEI for creating and maintaining the Integrated Global Radiosonde Archive dataset which we used for the bulk of the analysis in this paper (https: / www. ncdc.noaa.gov/data-access/weather-balloon/integrated-global-radiosonde-archive, accessed on 10 October 2021).

Conflicts of Interest: The authors declare no conflict of interest.

\section{References}

1. Tucker, G.B. The General Circulation of the Atmosphere. Weather 1962, 17, 320-340. [CrossRef]

2. Knox, J.A.; Knox, P.N. Atmospheric/General Circulation. In International Encyclopedia of Geography; American Cancer Society: Atlanta, GA, USA, 2017; pp. 1-8, ISBN 978-1-118-78635-2.

3. Durre, I.; Vose, R.S.; Wuertz, D.B. Overview of the Integrated Global Radiosonde Archive. J. Clim. 2006, 19, 53-68. [CrossRef]

4. Durre, I.; Vose, R.S.; Wuertz, D.B. Robust Automated Quality Assurance of Radiosonde Temperatures. J. Appl. Meteor. Climatol. 2008, 47, 2081-2095. [CrossRef]

5. Durre, I.; Yin, X.; Vose, R.S.; Applequist, S.; Arnfield, J. Enhancing the Data Coverage in the Integrated Global Radiosonde Archive. J. Atmos. Ocean. Technol. 2018, 35, 1753-1770. [CrossRef]

6. Lorenz, E.N. The Nature and Theory of the General Circulation of the Atmosphere; World Meteorological Organization: Geneva, Switzerland, 1967.

7. Webster, P.J. The Elementary Hadley Circulation. In The Hadley Circulation: Present, Past and Future; Diaz, H.F., Bradley, R.S., Eds.; Advances in Global Change Research; Springer: Dordrecht, The Netherlands, 2004; pp. 9-60, ISBN 978-1-4020-2944-8.

8. Persson, A.O. Hadley's Principle: Understanding and Misunderstanding the Trade Winds. Hist. Meteorol. $2006,3,26$.

9. Lu, J.; Vecchi, G.A. Tropical Meteorology \& Climate I Hadley Circulation. In Encyclopedia of Atmospheric Sciences, 2nd ed.; North, G.R., Pyle, J., Zhang, F., Eds.; Academic Press: Oxford, UK, 2015; pp. 113-120, ISBN 978-0-12-382225-3.

10. University of Chicago (Department of Meteorology). On the General Circulation of the Atmosphere in Middle Latitudes: A Preliminary Summary Report on Certain Investigations Conducted at the University of Chicago during the Academic Year 1946-1947. Bull. Am. Meteorol. Soc. 1947, 28, 255-280. [CrossRef]

11. Rossby, C.G.; Willett, H.C. The Circulation of the Upper Troposphere and Lower Stratosphere. Science 1948, $108,643-652$. [CrossRef]

12. Lewis, J.M.; Fearon, M.G.; Klieforth, H.E. Herbert Riehl: Intrepid and Enigmatic Scholar. Bull. Am. Meteorol. Soc. 2012, 93, 963-985. [CrossRef]

13. Lewis, J.M. Clarifying the Dynamics of the General Circulation: Phillips's 1956 Experiment. Bull. Am. Meteorol. Soc. 1998, 79, 39-60. [CrossRef]

14. Rossby, C.-G.; Starr, V.P. Interpretations of the Angular-Momentum Principle as Applied to the General Circulation of the Atmosphere. J. Atmos. Sci. 1949, 6, 288. [CrossRef]

15. Palmen, E. Meridional Circulations and the Transfer of Angular Momentum in the Atmosphere. J. Atmos. Sci. 1949, 6, 429-430. [CrossRef]

16. Starr, V.P. Reply. J. Atmos. Sci. 1949, 6, 430. [CrossRef]

17. Starr, V.P. A Note on the Eddy Transport of Angular Momentum. Q. J. R. Meteorol. Soc. 1951, 77, 44-50. [CrossRef]

18. Starr, V.P.; White, R.M. A Hemispherical Study of the Atmospheric Angular-Momentum Balance. Q. J. R. Meteorol. Soc. 1951, 77, 215-225. [CrossRef]

19. Starr, V.P. Note Concerning the Nature of the Large-Scale Eddies in the Atmosphere. Tellus 1953, 5, 494-498. [CrossRef]

20. Kuo, H.-L. On the Production of Mean Zonal Currents in the Atmosphere by Large Disturbances. Tellus 1953, 5, 475-493. [CrossRef]

21. Starr, V.P. Commentaries Concerning Research on the General Circulation. Tellus 1954, 6, 268-272. [CrossRef]

22. Starr, V.P. What Constitutes Our New Outlook Dot the General Circulation? J. Met. Soc. Japan 1958, 36, 167-173. [CrossRef]

23. Starr, V.P. Trends of Thought Concerning Meteorological Research. Geofis. Pura Appl. 1959, 43, 269-277. [CrossRef]

24. Newell, R.E. The General Circulation of the Atmosphere and Its Effects on the Movement of Trace Substances. J. Geophys. Res. 1963, 68, 3949-3962. [CrossRef]

25. Rossby, C.-G. On the Distribution of Angular Velocity in Gaseous Envelopes Under the Influence of Large-Scale Horizontal Mixing Processes. Bull. Am. Meteorol. Soc. 1947, 28, 53-68. [CrossRef]

26. Priestley, C.H.B. Heat Transport and Zonal Stress between Latitudes. Q. J. R. Meteorol. Soc. 1949, 75, 28-40. [CrossRef]

27. Priestley, C.H.B. On the Dynamics of the General Atmospheric Circulation. Aust. J. Chem. 1950, 3, 1-18. [CrossRef] 
28. Riehl, H.; Yeh, T.C. The Intensity of the Net Meridional Circulation. Q. J. R. Meteorol. Soc. 1950, 76, 182-188. [CrossRef]

29. Riehl, H.; Yeh, T.C.; Seur, N.E.L. A Study of the Variations of the General Circulation. J. Atmos. Sci. 1950, 7, 181-194. [CrossRef]

30. Phillips, N.A. The General Circulation of the Atmosphere: A Numerical Experiment. Q. J. R. Meteorol. Soc. 1956, 82, 123-164. [CrossRef]

31. Tucker, G.B. Evidence of a Mean Meridional Circulation in the Atmosphere from Surface Wind Observations. Q. J. R. Meteorol. Soc. 1957, 83, 290-302. [CrossRef]

32. Palmén, E.; Riehl, H.; Vuorela, L.A. On the Meridional Circulation and Release of Kinetic Energy in the Tropics. J. Atmos. Sci. 1958, 15, 271-277. [CrossRef]

33. Tucker, G.B. Mean Meridional Circulations in the Atmosphere. Q. J. R. Meteorol. Soc. 1959, 85, 209-224. [CrossRef]

34. Tucker, G.B. The Atmospheric Budget of Angular Momentum. Tellus 1960, 12, 134-144. [CrossRef]

35. Palmén, E.; Vuorela, L.A. On the Mean Meridional Circulations in the Northern Hemisphere during the Winter Season. Q. J. R. Meteorol. Soc. 1963, 89, 131-138. [CrossRef]

36. Defant, F.; Boogaard, H.M.E.V.D. The Global Circulation Features of the Troposphere between the Equator and $40^{\circ} \mathrm{N}$, Based on a Single Day's Data. Tellus 1963, 15, 251-260. [CrossRef]

37. Holopainen, E.O. On the Role of Mean Meridional Circulations in the Energy Balance of the Atmosphere. Tellus 1965, 17, 285-294. [CrossRef]

38. Holopainen, E.O. On the Mean Meridional Circulation and the Flux of Angular Momentum over the Northern Hemisphere. Tellus 1967, 19, 2-13. [CrossRef]

39. Vuorela, L.A.; Tuominen, I. On the Mean Zonal and Meridional Circulations and the Flux of Moisture in the Northern Hemisphere during the Summer Season. Pure Appl. Geophys. 1964, 57, 167-180. [CrossRef]

40. Hastenrath, S.L. A Study of the Atmospheric Circulation between Equator and $60 \mathrm{oN}$ during the Winter and Summer Seasons. Pure Appl. Geophys. 1969, 77, 207-226. [CrossRef]

41. Murray, R.; Parker, A.E.; Collison, P. Some Computations of Meridional Flow, Angular Momentum and Energy in the Atmosphere Based on IGY Data for Latitude $30^{\circ}$ N. Q. J. R. Meteorol. Soc. 1969, 95, 92-103. [CrossRef]

42. Kidson, J.W.; Vincent, D.G.; Newell, R.E. Observational Studies of the General Circulation of the Tropics: Long Term Mean Values. Q. J. R. Meteorol. Soc. 1969, 95, 258-287. [CrossRef]

43. Oort, A.H.; Rasmusson, E.M. On the Annual Variation of the Monthly Mean Meridional Circulation. Mon. Weather. Rev. 1970, 98, 423-442. [CrossRef]

44. Starr, V.P.; Peixoto, J.P.; Gaut, N.E. Momentum and Zonal Kinetic Energy Balance of the Atmosphere from Five Years of Hemispheric Data. Tellus 1970, 22, 251-274. [CrossRef]

45. Schulman, L.L. On the Summer Hemisphere Hadley Cell. Q. J. R. Meteorol. Soc. 1973, 99, 197-201. [CrossRef]

46. Schneider, E.K.; Lindzen, R.S. Axially Symmetric Steady-State Models of the Basic State for Instability and Climate Studies. Part, I. Linearized Calculations. J. Atmos. Sci. 1977, 34, 263-279. [CrossRef]

47. Held, I.M.; Hou, A.Y. Nonlinear Axially Symmetric Circulations in a Nearly Inviscid Atmosphere. J. Atmos. Sci. 1980, 37, 515-533. [CrossRef]

48. Lindzen, R.S.; Hou, A.V. Hadley Circulations for Zonally Averaged Heating Centered off the Equator. J. Atmos. Sci. 1988, 45, 2416-2427. [CrossRef]

49. Lutgens, F.K.; Tarbuck, E.J.; Tasa, D.G. The Atmosphere: An Introduction to Meteorology, 11th ed.; Pearson: New York, NY, USA, 2009; ISBN 978-0-321-58733-6.

50. Walker, C.C.; Schneider, T. Eddy Influences on Hadley Circulations: Simulations with an Idealized GCM. J. Atmos. Sci. 2006, 63, 3333-3350. [CrossRef]

51. Davis, N.A.; Birner, T. Eddy Influences on the Hadley Circulation. J. Adv. Model. Earth Syst. 2019, 11, 1563-1581. [CrossRef]

52. Wang, W.-L.; Wang, Y.; Wu, R.-S. A New View on the Ferrel Cell. Chin. J. Geophys. 2005, 48, 539-545. [CrossRef]

53. Qian, W.; Wu, K.; Chen, D. The Arctic and Polar Cells Act on the Arctic Sea Ice Variation. Tellus A Dyn. Meteorol. Oceanogr. 2015, 67, 27692. [CrossRef]

54. Qian, W.; Wu, K.; Liang, H. Arctic and Antarctic Cells in the Troposphere. Theor. Appl. Climatol. 2016, 125, 1-12. [CrossRef]

55. Qian, W.; Wu, K.; Leung, J.C.-H. Climatic Anomalous Patterns Associated with the Arctic and Polar Cell Strength Variations. Clim. Dyn. 2017, 48, 169-189. [CrossRef]

56. Oort, A.H.; Yienger, J.J. Observed Interannual Variability in the Hadley Circulation and Its Connection to ENSO. J. Clim. 1996, 9 , 2751-2767. [CrossRef]

57. Wang, C. Atmospheric Circulation Cells Associated with the El Niño-Southern Oscillation. J. Clim. 2002, 15, 399-419. [CrossRef]

58. Wang, C. Atlantic Climate Variability and Its Associated Atmospheric Circulation Cells. J. Clim. 2002, 15, 1516-1536. [CrossRef]

59. Ding, Q.; Wang, B. Circumglobal Teleconnection in the Northern Hemisphere Summer. J. Clim. 2005, 18, 3483-3505. [CrossRef]

60. Wang, B.; Ding, Q. Global Monsoon: Dominant Mode of Annual Variation in the Tropics. Dyn. Atmos. Ocean. 2008, 44, 165-183. [CrossRef]

61. Wang, B.; Liu, J.; Kim, H.-J.; Webster, P.J.; Yim, S.-Y.; Xiang, B. Northern Hemisphere Summer Monsoon Intensified by Mega-El Niño/Southern Oscillation and Atlantic Multidecadal Oscillation. Proc. Natl. Acad. Sci. USA 2013, 110, 5347-5352. [CrossRef] [PubMed] 
62. Yun, K.-S.; Timmermann, A.; Stuecker, M.F. Synchronized Spatial Shifts of Hadley and Walker Circulations. Earth Syst. Dyn. 2021, 12, 121-132. [CrossRef]

63. Schwendike, J.; Govekar, P.; Reeder, M.J.; Wardle, R.; Berry, G.J.; Jakob, C. Local Partitioning of the Overturning Circulation in the Tropics and the Connection to the Hadley and Walker Circulations. J. Geophys. Res. Atmos. 2014, 119, 1322-1339. [CrossRef]

64. Schwendike, J.; Berry, G.J.; Reeder, M.J.; Jakob, C.; Govekar, P.; Wardle, R. Trends in the Local Hadley and Local Walker Circulations. J. Geophys. Res. Atmos. 2015, 120, 7599-7618. [CrossRef]

65. Schwendike, J.; Berry, G.J.; Fodor, K.; Reeder, M.J. On the Relationship Between the Madden-Julian Oscillation and the Hadley and Walker Circulations. J. Geophys. Res. Atmos. 2021, 126, e2019JD032117. [CrossRef]

66. Karnauskas, K.B.; Ummenhofer, C.C. On the Dynamics of the Hadley Circulation and Subtropical Drying. Clim. Dyn. 2014, 42, 2259-2269. [CrossRef]

67. Thompson, D.W.J.; Wallace, J.M. Annular Modes in the Extratropical Circulation. Part I: Month-to-Month Variability. J. Clim. 2000, 13, 1000-1016. [CrossRef]

68. Li, X.-F.; Li, J.; Zhang, X.; Sun, C. Role of Ferrel Cell in Daily Variability of Northern Hemisphere Annular Mode. Chin. Sci. Bull. 2014, 59, 3457-3464. [CrossRef]

69. Hu, D.; Guo, Y.-P.; Tan, Z.-M.; Guan, Z. Interannual Relationship between the Boreal Spring Arctic Oscillation and the Northern Hemisphere Hadley Circulation Extent. J. Clim. 2019, 32, 4395-4408. [CrossRef]

70. Liu, J.; Curry, J.A.; Hu, Y. Recent Arctic Sea Ice Variability: Connections to the Arctic Oscillation and the ENSO. Geophys. Res. Lett. 2004, 31. [CrossRef]

71. Kryzhov, V.N.; Gorelits, O.V. The Arctic Oscillation and Its Impact on Temperature and Precipitation in Northern Eurasia in the 20th Century. Russ. Meteorol. Hydrol. 2015, 40, 711-721. [CrossRef]

72. Georgieva, K.; Kirov, B.; Tonev, P.; Guineva, V.; Atanasov, D. Long-Term Variations in the Correlation between NAO and Solar Activity: The Importance of North-South Solar Activity Asymmetry for Atmospheric Circulation. Adv. Space Res. 2007, 40, 1152-1166. [CrossRef]

73. Soon, W.; Connolly, R.; Connolly, M. Re-Evaluating the Role of Solar Variability on Northern Hemisphere Temperature Trends since the 19th Century. Earth Sci. Rev. 2015, 150, 409-452. [CrossRef]

74. Cionco, R.G.; Valentini, J.E.; Quaranta, N.E.; Soon, W.W.-H. Lunar Fingerprints in the Modulated Incoming Solar Radiation: In Situ Insolation and Latitudinal Insolation Gradients as Two Important Interpretative Metrics for Paleoclimatic Data Records and Theoretical Climate Modeling. New Astron. 2018, 58, 96-106. [CrossRef]

75. Cionco, R.G.; Soon, W.W.-H.; Quaranta, N.E. On the Calculation of Latitudinal Insolation Gradients throughout the Holocene. Adv. Space Res. 2020, 66, 720-742. [CrossRef]

76. Connolly, R.; Soon, W.; Connolly, M.; Baliunas, S.; Berglund, J.; Butler, C.J.; Cionco, R.G.; Elias, A.G.; Fedorov, V.M.; Harde, H.; et al. How Much Has the Sun Influenced Northern Hemisphere Temperature Trends? An Ongoing Debate. Res. Astron. Astrophys. 2021, 21, 131. [CrossRef]

77. Durre, I.; Yin, X. Enhanced Radiosonde Data for Studies of Vertical Structure. Bull. Am. Meteorol. Soc. 2008, 89, 1257-1262. [CrossRef]

78. Meehl, G.A.; Arblaster, J.M.; Matthes, K.; Sassi, F.; Loon, H. van Amplifying the Pacific Climate System Response to a Small 11-Year Solar Cycle Forcing. Science 2009, 325, 1114-1118. [CrossRef] [PubMed]

79. van Loon, H.; Meehl, G.A. The Average Influence of Decadal Solar Forcing on the Atmosphere in the South Pacific Region. Geophys. Res. Lett. 2011, 38. [CrossRef]

80. Huo, W.; Xiao, Z. Modulations of Solar Activity on El Niño Modoki and Possible Mechanisms. J. Atmos. Sol. Terr. Phys. 2017, 160, 34-47. [CrossRef]

81. Lukianova, R.; Alekseev, G. Long-Term Correlation Between the Nao and Solar Activity. Sol. Phys. 2004, 224, 445-454. [CrossRef]

82. Boberg, F.; Lundstedt, H. Solar Wind Electric Field Modulation of the NAO: A Correlation Analysis in the Lower Atmosphere. Geophys. Res. Lett. 2003, 30, 1825. [CrossRef]

83. Van Loon, H.; Brown, J.; Milliff, R.F. Trends in Sunspots and North Atlantic Sea Level Pressure. J. Geophys. Res. Atmos. 2012, 117. [CrossRef]

84. El-Borie, M.A.; Thabet, A.A.; El-Mallah, E.S.; Abd El-Zaher, M.; Bishara, A.A. The Combined Influences for Solar-Geomagnetic Activities and the Atmospheric Circulation NAO on Global Surface Temperatures. Indian J. Phys. 2021, 95, 1041-1049. [CrossRef]

85. Kuroda, Y.; Kodera, K.; Yoshida, K.; Yukimoto, S.; Gray, L.J. Influence of the Solar Cycle on the North Atlantic Oscillation. Available online: http:/ / www.essoar.org/doi/10.1002/essoar.10507546.1 (accessed on 22 September 2021).

86. Hernández, A.; Sánchez-López, G.; Pla-Rabes, S.; Comas-Bru, L.; Parnell, A.; Cahill, N.; Geyer, A.; Trigo, R.M.; Giralt, S. A 2,000-Year Bayesian NAO Reconstruction from the Iberian Peninsula. Sci. Rep. 2020, 10, 14961. [CrossRef]

87. Ait Brahim, Y.; Wassenburg, J.A.; Cruz, F.W.; Sifeddine, A.; Scholz, D.; Bouchaou, L.; Dassié, E.P.; Jochum, K.P.; Edwards, R.L.; Cheng, H. Multi-Decadal to Centennial Hydro-Climate Variability and Linkage to Solar Forcing in the Western Mediterranean during the Last 1000 Years. Sci. Rep. 2018, 8, 17446. [CrossRef]

88. Ruzmaikin, A.; Feynman, J.; Jiang, X.; Noone, D.C.; Waple, A.M.; Yung, Y.L. The Pattern of Northern Hemisphere Surface Air Temperature during Prolonged Periods of Low Solar Output. Geophys. Res. Lett. 2004, 31, L12201. [CrossRef]

89. Hoffmann, C.G.; von Savigny, C. Indications for a Potential Synchronization between the Phase Evolution of the Madden-Julian Oscillation and the Solar 27-Day Cycle. Atmos. Chem. Phys. 2019, 19, 4235-4256. [CrossRef] 
90. Le Mouël, J.-L.; Lopes, F.; Courtillot, V. A Solar Signature in Many Climate Indices. J. Geophys. Res. Atmos. 2019, 124, 2600-2619. [CrossRef]

91. Maruyama, F. The Relation among the Solar Activity, the Total Ozone, QBO, NAO, and ENSO by Wavelet-Based Multifractal Analysis. J. Appl. Math. Phys. 2018, 6, 1301-1314. [CrossRef]

92. Singh, P.R.; Tiwari, C.M.; Agrawal, S.L.; Pant, T.K. Periodicity Variation of Solar Activity and Cosmic Rays During Solar Cycles 22-24. Sol. Phys. 2019, 294, 118. [CrossRef]

93. Zhang, C.; Zhang, B. QBO-MJO Connection. J. Geophys. Res. Atmos. 2018, 123, 2957-2967. [CrossRef]

94. Kim, H.; Caron, J.M.; Richter, J.H.; Simpson, I.R. The Lack of QBO-MJO Connection in CMIP6 Models. Geophys. Res. Lett. 2020, 47, e2020GL087295. [CrossRef]

95. Christoforou, P.; Hameed, S. Solar Cycle and the Pacific 'centers of Action'. Geophys. Res. Lett. 1997, 24, 293-296. [CrossRef]

96. Sfîcă, L.; Voiculescu, M. Possible Effects of Atmospheric Teleconnections and Solar Variability on Tropospheric and Stratospheric Temperatures in the Northern Hemisphere. J. Atmos. Sol. Terr. Phys. 2014, 109, 7-14. [CrossRef]

97. Sfîcă, L.; Iordache, I.; Voiculescu, M. Solar Signal on Regional Scale: A Study of Possible Solar Impact upon Romania's Climate. J. Atmos. Sol. Terr. Phys. 2018, 177, 257-265. [CrossRef]

98. Roy, I. The Role of the Sun in Atmosphere-Ocean Coupling. Int. J. Climatol. 2014, 34, 655-677. [CrossRef]

99. Roy, I. Climate Variability and Sunspot Activity: Analysis of the Solar Influence on Climate; Springer Atmospheric Sciences; Springer International Publishing: Berlin/Heidelberg, Germany, 2018; ISBN 978-3-319-77106-9.

100. Dobrica, V.; Pirloaga, R.; Stefan, C.; Demetrescu, C. Inferring Geoeffective Solar Variability Signature in Stratospheric and Tropospheric Northern Hemisphere Temperatures. J. Atmos. Sol. Terr. Phys. 2018, 180, 137-147. [CrossRef]

101. Yan, D.; Xu, H.; Lan, J.; Zhou, K.; Ye, Y.; Zhang, J.; An, Z.; Yeager, K.M. Solar Activity and the Westerlies Dominate Decadal Hydroclimatic Changes over Arid Central Asia. Glob. Planet. Chang. 2019, 173, 53-60. [CrossRef]

102. Lüdecke, H.-J.; Cina, R.; Dammschneider, H.-J.; Lüning, S. Decadal and Multidecadal Natural Variability in European Temperature. J. Atmos. Sol.-Terr. Phys. 2020, 205, 105294. [CrossRef]

103. Veretenenko, S.; Ogurtsov, M. Regional and Temporal Variability of Solar Activity and Galactic Cosmic Ray Effects on the Lower Atmosphere Circulation. Adv. Space Res. 2012, 49, 770-783. [CrossRef]

104. Ogurtsov, M.; Lindholm, M.; Jalkanen, R.; Veretenenko, S. Evidence for the Gleissberg Solar Cycle at the High-Latitudes of the Northern Hemisphere. Adv. Space Res. 2015, 55, 1285-1290. [CrossRef]

105. Veretenenko, S.; Ogurtsov, M. Manifestation and Possible Reasons of 60-Year Oscillations in Solar-Atmospheric Links. Adv. Space Res. 2019, 64, 104-116. [CrossRef]

106. Ogurtsov, M. Decadal and Bi-Decadal Periodicities in Temperature of Southern Scandinavia: Manifestations of Natural Variability or Climatic Response to Solar Cycles? Atmosphere 2021, 12, 676. [CrossRef]

107. Waliser, D.E.; Shi, Z.; Lanzante, J.R.; Oort, A.H. The Hadley Circulation: Assessing NCEP/NCAR Reanalysis and Sparse in-Situ Estimates. Clim. Dyn. 1999, 15, 719-735. [CrossRef]

108. Mitas, C.M.; Clement, A. Has the Hadley Cell Been Strengthening in Recent Decades? Geophys. Res. Lett. 2005, 32. [CrossRef]

109. Johanson, C.M.; Fu, Q. Hadley Cell Widening: Model Simulations versus Observations. J. Clim. 2009, 22, 2713-2725. [CrossRef]

110. Stachnik, J.P.; Schumacher, C. A Comparison of the Hadley Circulation in Modern Reanalyses. J. Geophys. Res. Atmos. 2011, 116. [CrossRef]

111. Liu, J.; Song, M.; Hu, Y.; Ren, X. Changes in the Strength and Width of the Hadley Circulation since 1871. Clim. Past 2012, 8, 1169-1175. [CrossRef]

112. Nguyen, H.; Evans, A.; Lucas, C.; Smith, I.; Timbal, B. The Hadley Circulation in Reanalyses: Climatology, Variability, and Change. J. Clim. 2013, 26, 3357-3376. [CrossRef]

113. Hersbach, H.; Bell, B.; Berrisford, P.; Hirahara, S.; Horányi, A.; Muñoz-Sabater, J.; Nicolas, J.; Peubey, C.; Radu, R.; Schepers, D.; et al. The ERA5 Global Reanalysis. Q. J. R. Meteorol. Soc. 2020, 146, 1999-2049. [CrossRef]

114. Lu, J.; Vecchi, G.A.; Reichler, T. Expansion of the Hadley Cell under Global Warming. Geophys. Res. Lett. 2007, 34. [CrossRef]

115. Garfinkel, C.I.; Waugh, D.W.; Polvani, L.M. Recent Hadley Cell Expansion: The Role of Internal Atmospheric Variability in Reconciling Modeled and Observed Trends. Geophys. Res. Lett. 2015, 42, 10824-10831. [CrossRef]

116. Guo, Y.-P.; Li, J.-P.; Feng, J. Climatology and Interannual Variability of the Annual Mean Hadley Circulation in CMIP5 Models. Adv. Clim. Chang. Res. 2016, 7, 35-45. [CrossRef]

117. Davis, N.; Birner, T. On the Discrepancies in Tropical Belt Expansion between Reanalyses and Climate Models and among Tropical Belt Width Metrics. J. Clim. 2017, 30, 1211-1231. [CrossRef]

118. Grise, K.M.; Davis, S.M. Hadley Cell Expansion in CMIP6 Models. Atmos. Chem. Phys. 2020, 20, 5249-5268. [CrossRef]

119. Xia, Y.; Hu, Y.; Liu, J. Comparison of Trends in the Hadley Circulation between CMIP6 and CMIP5. Sci. Bull. 2020, 65, 1667-1674. [CrossRef]

120. Lucas, C.; Timbal, B.; Nguyen, H. The Expanding Tropics: A Critical Assessment of the Observational and Modeling Studies. WIREs Clim. Chang. 2014, 5, 89-112. [CrossRef]

121. Allen, R.J.; Kovilakam, M. The Role of Natural Climate Variability in Recent Tropical Expansion. J. Clim. 2017, 30, 6329-6350. [CrossRef]

122. Hu, Y.; Huang, H.; Zhou, C. Widening and Weakening of the Hadley Circulation under Global Warming. Sci. Bull. 2018, 63, 640-644. [CrossRef] 
123. Davis, N.A.; Davis, S.M. Reconciling Hadley Cell Expansion Trend Estimates in Reanalyses. Geophys. Res. Lett. 2018, 45, 11439-11446. [CrossRef]

124. Chemke, R.; Polvani, L.M. Opposite Tropical Circulation Trends in Climate Models and in Reanalyses. Nat. Geosci. 2019, 12, 528-532. [CrossRef]

125. Lucas, C.; Nguyen, H.; Timbal, B. An Observational Analysis of Southern Hemisphere Tropical Expansion. J. Geophys. Res. Atmos. 2012, 117, D17112. [CrossRef]

126. Davis, N.A.; Birner, T. Seasonal to Multidecadal Variability of the Width of the Tropical Belt. J. Geophys. Res. Atmos. 2013, 118, 7773-7787. [CrossRef]

127. Solomon, A.; Polvani, L.M.; Waugh, D.W.; Davis, S.M. Contrasting Upper and Lower Atmospheric Metrics of Tropical Expansion in the Southern Hemisphere. Geophys. Res. Lett. 2016, 43, 10496-10503. [CrossRef]

128. Hu, Y.; Zhou, C.; Liu, J. Observational Evidence for Poleward Expansion of the Hadley Circulation. Adv. Atmos. Sci. 2011, 28, 33-44. [CrossRef]

129. Connolly, R.; Connolly, M.; Soon, W.; Legates, D.R.; Cionco, R.G.; Velasco Herrera, V.M. Northern Hemisphere Snow-Cover Trends (1967-2018): A Comparison between Climate Models and Observations. Geosciences 2019, 9, 135. [CrossRef]

130. McKitrick, R.; Christy, J. Pervasive Warming Bias in CMIP6 Tropospheric Layers. Earth Space Sci. 2020, 7, e2020EA001281. [CrossRef]

131. Stith, J.L.; Baumgardner, D.; Haggerty, J.; Hardesty, R.M.; Lee, W.-C.; Lenschow, D.; Pilewskie, P.; Smith, P.L.; Steiner, M.; Vömel, H. 100 Years of Progress in Atmospheric Observing Systems. Meteorol. Monogr. 2018, 59, 2.1-2.55. [CrossRef]

132. Wilczak, J.M.; Gossard, E.E.; Neff, W.D.; Eberhard, W.L. Ground-Based Remote Sensing of the Atmospheric Boundary Layer: 25 Years of Progress. In Boundary-Layer Meteorology 25th Anniversary Volume, 1970-1995: Invited Reviews and Selected Contributions to Recognise Ted Munn's Contribution as Editor over the Past 25 Years; Garratt, J.R., Taylor, P.A., Eds.; Springer: Dordrecht, The Netherlands, 1996; pp. 321-349, ISBN 978-94-017-0944-6.

133. Bianco, L.; Friedrich, K.; Wilczak, J.M.; Hazen, D.; Wolfe, D.; Delgado, R.; Oncley, S.P.; Lundquist, J.K. Assessing the Accuracy of Microwave Radiometers and Radio Acoustic Sounding Systems for Wind Energy Applications. Atmos. Meas. Tech. 2017, 10, 1707-1721. [CrossRef]

134. Park, S.; Kim, S.-W.; Park, M.-S.; Song, C.-K. Measurement of Planetary Boundary Layer Winds with Scanning Doppler Lidar. Remote Sens. 2018, 10, 1261. [CrossRef]

135. Dang, R.; Yang, Y.; Hu, X.-M.; Wang, Z.; Zhang, S. A Review of Techniques for Diagnosing the Atmospheric Boundary Layer Height (ABLH) Using Aerosol Lidar Data. Remote Sens. 2019, 11, 1590. [CrossRef]

136. Terzi, L.; Wotawa, G.; Schoeppner, M.; Kalinowski, M.; Saey, P.R.J.; Steinmann, P.; Luan, L.; Staten, P.W. Radioisotopes Demonstrate Changes in Global Atmospheric Circulation Possibly Caused by Global Warming. Sci. Rep. 2020, 10, 10695. [CrossRef] [PubMed]

137. Baron, P.; Murtagh, D.; Eriksson, P.; Mendrok, J.; Ochiai, S.; Pérot, K.; Sagawa, H.; Suzuki, M. Simulation Study for the Stratospheric Inferred Winds (SIW) Sub-Millimeter Limb Sounder. Atmos. Meas. Tech. 2018, 11, 4545-4566. [CrossRef]

138. Duruisseau, F.; Huret, N.; Andral, A.; Camy-Peyret, C. Assessment of the ERA-Interim Winds Using High-Altitude Stratospheric Balloons. J. Atmos. Sci. 2017, 74, 2065-2080. [CrossRef]

139. Zhang, Y.; Li, D.; Lin, Z.; Santanello, J.A., Jr.; Gao, Z., Jr. Development and Evaluation of a Long-Term Data Record of Planetary Boundary Layer Profiles from Aircraft Meteorological Reports. J. Geophys. Res. Atmos. 2019, 124, 2008-2030. [CrossRef]

140. Connolly, M.; Connolly, R. The Physics of the Earth's Atmosphere, I. Phase Change Associated with Tropopause. Open Peer Rev. J. 2014, 19. Available online: http:/ / oprj.net/articles/atmospheric-science/19 (accessed on 25 October 2021).

141. Connolly, M.; Connolly, R. The Physics of the Earth's Atmosphere II. Multimerization of Atmospheric Gases above the Troposphere. Open Peer Rev. J. 2014, 22. Available online: http:/ / oprj.net/articles/atmospheric-science/22 (accessed on 25 October 2021).

142. Connolly, M.; Connolly, R. The Physics of the Earth's Atmosphere III. Pervective Power. Open Peer Rev. J. 2014, 25. Available online: http:/ / oprj.net/articles/atmospheric-science/25 (accessed on 25 October 2021).

143. Murphy, D.M.; Koop, T. Review of the Vapour Pressures of Ice and Supercooled Water for Atmospheric Applications. Quarterly J. R. Meteorol. Soc. 2005, 131, 1539-1565. [CrossRef]

144. Torrence, C.; Compo, G.P. A Practical Guide to Wavelet Analysis. Bull. Am. Meteorol. Soc. 1998, 79, 61-78. [CrossRef]

145. Soon, W.; Velasco Herrera, V.M.; Cionco, R.G.; Qiu, S.; Baliunas, S.; Egeland, R.; Henry, G.W.; Charvátová, I. Covariations of Chromospheric and Photometric Variability of the Young Sun Analogue HD 30495: Evidence for and Interpretation of Mid-Term Periodicities. Mon. Not. R. Astron. Soc. 2019, 483, 2748-2757. [CrossRef]

146. Velasco Herrera, V.M.; Soon, W.; Velasco Herrera, G.; Traversi, R.; Horiuchi, K. Generalization of the Cross-Wavelet Function. New Astron. 2017, 56, 86-93. [CrossRef]

147. Soon, W.; Velasco Herrera, V.M.; Selvaraj, K.; Traversi, R.; Usoskin, I.; Chen, C.-T.A.; Lou, J.-Y.; Kao, S.-J.; Carter, R.M.; Pipin, V.; et al. A Review of Holocene Solar-Linked Climatic Variation on Centennial to Millennial Timescales: Physical Processes, Interpretative Frameworks and a New Multiple Cross-Wavelet Transform Algorithm. Earth Sci. Rev. 2014, 134, 1-15. [CrossRef]

148. Hoinka, K.P. The Tropopause: Discovery, Definition and Demarcation. Meteorologische Zeitschrift 1997, 281-303. [CrossRef]

149. Kristoufek, L. Has Global Warming Modified the Relationship between Sunspot Numbers and Global Temperatures? Phys. A Stat. Mech. Appl. 2017, 468, 351-358. [CrossRef]

150. Gallegati, M. A Systematic Wavelet-Based Exploratory Analysis of Climatic Variables. Clim. Chang. 2018, 148, 325-338. [CrossRef] 
151. Cionco, R.G.; Kudryavtsev, S.M.; Soon, W.W.-H. Possible Origin of Some Periodicities Detected in Solar-Terrestrial Studies: Earth's Orbital Movements. Earth Space Sci. 2021, 8, e2021EA001805. [CrossRef]

152. Timmermans, M.-L.; Marshall, J. Understanding Arctic Ocean Circulation: A Review of Ocean Dynamics in a Changing Climate. J. Geophys. Res. Ocean. 2020, 125, e2018JC014378. [CrossRef]

153. He, J.; Winton, M.; Vecchi, G.; Jia, L.; Rugenstein, M. Transient Climate Sensitivity Depends on Base Climate Ocean Circulation. J. Clim. 2017, 30, 1493-1504. [CrossRef]

154. Du, Y.; Zhang, Y.; Shi, J. Relationship between Sea Surface Salinity and Ocean Circulation and Climate Change. Sci. China Earth Sci. 2019, 62, 771-782. [CrossRef] 